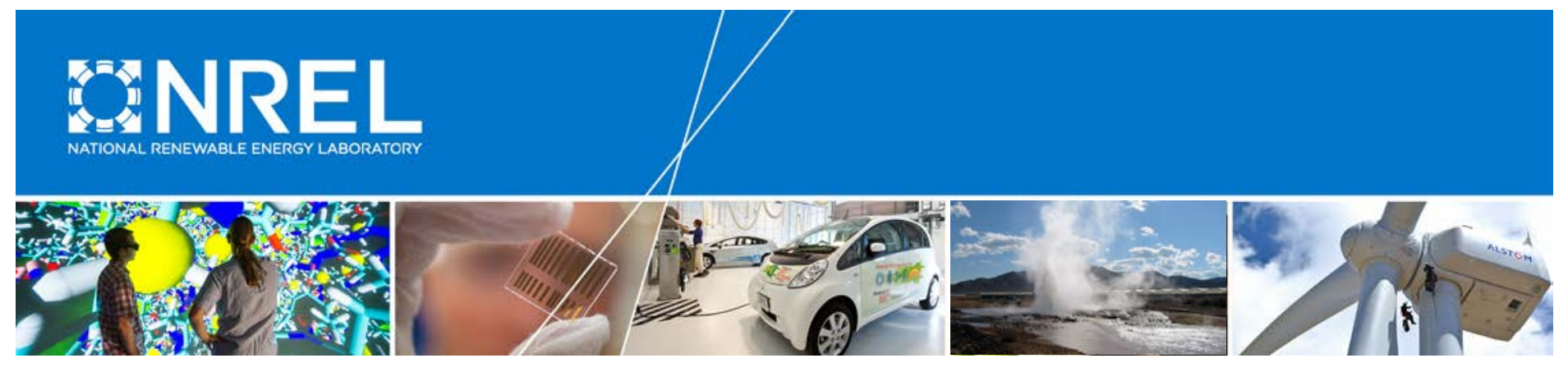

\title{
Doubling Geothermal Generation Capacity by 2020: A Strategic Analysis
}

Anna Wall and Katherine Young National Renewable Energy Laboratory

NREL is a national laboratory of the U.S. Department of Energy Office of Energy Efficiency \& Renewable Energy Operated by the Alliance for Sustainable Energy, LLC

This report is available at no cost from the National Renewable Energy Laboratory (NREL) at www.nrel.gov/publications.

Technical Report

NREL/TP-6A20-64925

January 2016

Contract No. DE-AC36-08G028308 


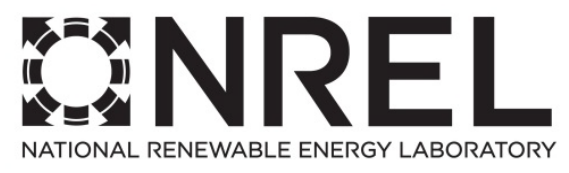

\title{
Doubling Geothermal Generation Capacity by 2020: A Strategic Analysis
}

\author{
Anna Wall and Katherine Young \\ National Renewable Energy Laboratory
}

Prepared under Task No. GTP5.0200

NREL is a national laboratory of the U.S. Department of Energy Office of Energy Efficiency \& Renewable Energy Operated by the Alliance for Sustainable Energy, LLC

This report is available at no cost from the National Renewable Energy Laboratory (NREL) at www.nrel.gov/publications.

National Renewable Energy Laboratory 15013 Denver West Parkway Golden, CO 80401 303-275-3000 • www.nrel.gov

\section{Technical Report}

NREL/TP-6A20-64925

January 2016

Contract No. DE-AC36-08G028308 


\section{NOTICE}

This report was prepared as an account of work sponsored by an agency of the United States government. Neither the United States government nor any agency thereof, nor any of their employees, makes any warranty, express or implied, or assumes any legal liability or responsibility for the accuracy, completeness, or usefulness of any information, apparatus, product, or process disclosed, or represents that its use would not infringe privately owned rights. Reference herein to any specific commercial product, process, or service by trade name, trademark, manufacturer, or otherwise does not necessarily constitute or imply its endorsement, recommendation, or favoring by the United States government or any agency thereof. The views and opinions of authors expressed herein do not necessarily state or reflect those of the United States government or any agency thereof.

This report is available at no cost from the National Renewable Energy Laboratory (NREL) at www.nrel.gov/publications.

Available electronically at SciTech Connect http:/www.osti.gov/scitech

Available for a processing fee to U.S. Department of Energy and its contractors, in paper, from:

U.S. Department of Energy

Office of Scientific and Technical Information

P.O. Box 62

Oak Ridge, TN 37831-0062

OSTI http://www.osti.gov

Phone: 865.576.8401

Fax: 865.576.5728

Email: reports@osti.gov

Available for sale to the public, in paper, from:

U.S. Department of Commerce

National Technical Information Service

5301 Shawnee Road

Alexandria, VA 22312

NTIS http://www.ntis.gov

Phone: 800.553 .6847 or 703.605 .6000

Fax: 703.605.6900

Email: orders@ntis.gov 


\section{Acknowledgments}

This work was supported by the U.S. Department of Energy, Office of Energy Efficiency and Renewable Energy, Geothermal Technologies Office (GTO) under Contract No. DE-AC36-08GO28308 with the National Renewable Energy Laboratory. The authors wish to thank Ben Matek at the Geothermal Energy Association, Andy Sabin at the Naval Geothermal Program, Josh Nordquist and Yoram Bronicki at Ormat Nevada Inc., Maureen McIntyre at McIntyre Communications Inc., Tim Reinhardt at GTO, and the NREL review team, including Connie Komomua, Liz Doris, Sherry Stout, Chad Augustine, Emily Newes, and Maggie Mann. 


$\begin{array}{ll}\text { List of Acronyms } \\ \text { BLM } & \text { U.S. Bureau of Land Management } \\ \text { DOE } & \text { U.S. Department of Energy } \\ \text { EIA } & \text { U.S. Energy Information Administration } \\ \text { FERC } & \text { U.S. Federal Energy Regulatory Commission } \\ \text { GEA } & \text { Geothermal Energy Association } \\ \text { GTO } & \text { DOE's Geothermal Technologies Office } \\ \text { GWe } & \text { gigawatt of electricity } \\ \text { IPP } & \text { independent power producer } \\ \text { KGRA } & \text { known geothermal resource area } \\ \text { NEPA } & \text { National Environmental Policy Act } \\ \text { NIMBY } & \text { not in my backyard } \\ \text { NREL } & \text { National Renewable Energy Laboratory } \\ \text { OpenEI } & \text { Open Energy Information } \\ \text { PPA } & \text { power purchase agreement } \\ \text { ReEDs } & \text { Regional Energy Deployment System Model } \\ \text { RPS } & \text { renewable portfolio standard } \\ \text { SEC } & \text { U.S. Securities and Exchange Commission } \\ \text { TGH } & \text { temperature gradient holes } \\ \text { USGS } & \text { U.S. Geological Survey } \\ & \end{array}$




\section{Executive Summary}

The President's Climate Action Plan, issued by the Executive Office of the President in June 2013, set forth a goal of doubling renewable energy generation in the United States by 2020. President Obama then signed a memorandum in December 2013 that directs the federal government to consume $20 \%$ of its electricity from renewable sources by $2020 .{ }^{1}$ This percentage is more than double the current level of renewable energy consumption in the United States.

The President's plan does not specify which renewable energy resources must increase to meet the goal. At the direction of the U.S. Department of Energy's Geothermal Technologies Office, the National Renewable Energy Laboratory (NREL) investigated the feasibility of geothermal energy significantly contributing to the President's goal of doubling United States renewable energy generation by 2020 . To do so, geothermal generation capacity in the United States would have to increase from the current level of approximately $3.8 \mathrm{GWe}$ to $7.6 \mathrm{GWe}$.

Geothermal projects typically require a minimum of five years from the time they are first identified as a prospect to the time they come online (e.g., Flóvenz 2013; Glacier Partners 2009). Therefore, the NREL team focused a strategic analysis on projects already in development that could come online by 2020 , as well as the barriers that could impede progress.

The Geothermal Energy Association (GEA) has listed 6.4 GWe of unique geothermal projects in development in years 2012 through 2015 (GEA 2015, 2014, 2013, 2012). It is estimated that these projects have the potential to more than double geothermal generation in the United States-if they were all to come online in the next 5 years.

NREL reviewed these 230 geothermal projects to identify which projects were most likely to advance the doubling effort. We catalogued the potential capacity of projects that have been discontinued or postponed, but only considered projects in progress (i.e. not discontinued) as having the ability to contribute to the near-term supply of geothermal power. For these projects, this analysis identified the types and pervasiveness of barriers to development, including conclusions on the availability of adequate resources for commercial production, considering factors such as the geographic distribution and maturity of exploration to date.

Our results show that over half of these listed projects are in early stages of development, and therefore still face barriers of development risk and uncertainty outside of the specific barriers explored in this analysis.

This analysis examined each project to determine which ones are likely to come online within the 2020 timeframe. The results of the analysis (Figure ES-1) show:

- $\quad 1.63 \mathrm{GWe}$ - Discontinued projects

- $\quad 0.70 \mathrm{GWe}$ - Postponed projects (with public information available)

- $\quad 0.07 \mathrm{GWe}$ - Postponed projects (with no further information on project barriers)

1 Since this analysis was completed, an executive order was issued updating the goals to 30\% renewables by 2025 . https://www.whitehouse.gov/the-press-office/2015/03/19/executive-order-planning-federal-sustainability-nextdecade 
- $2.66 \mathrm{GWe}$ - Ongoing projects (with public information available)

- $1.38 \mathrm{GWe}$ - Ongoing projects (with no further information on project barriers).

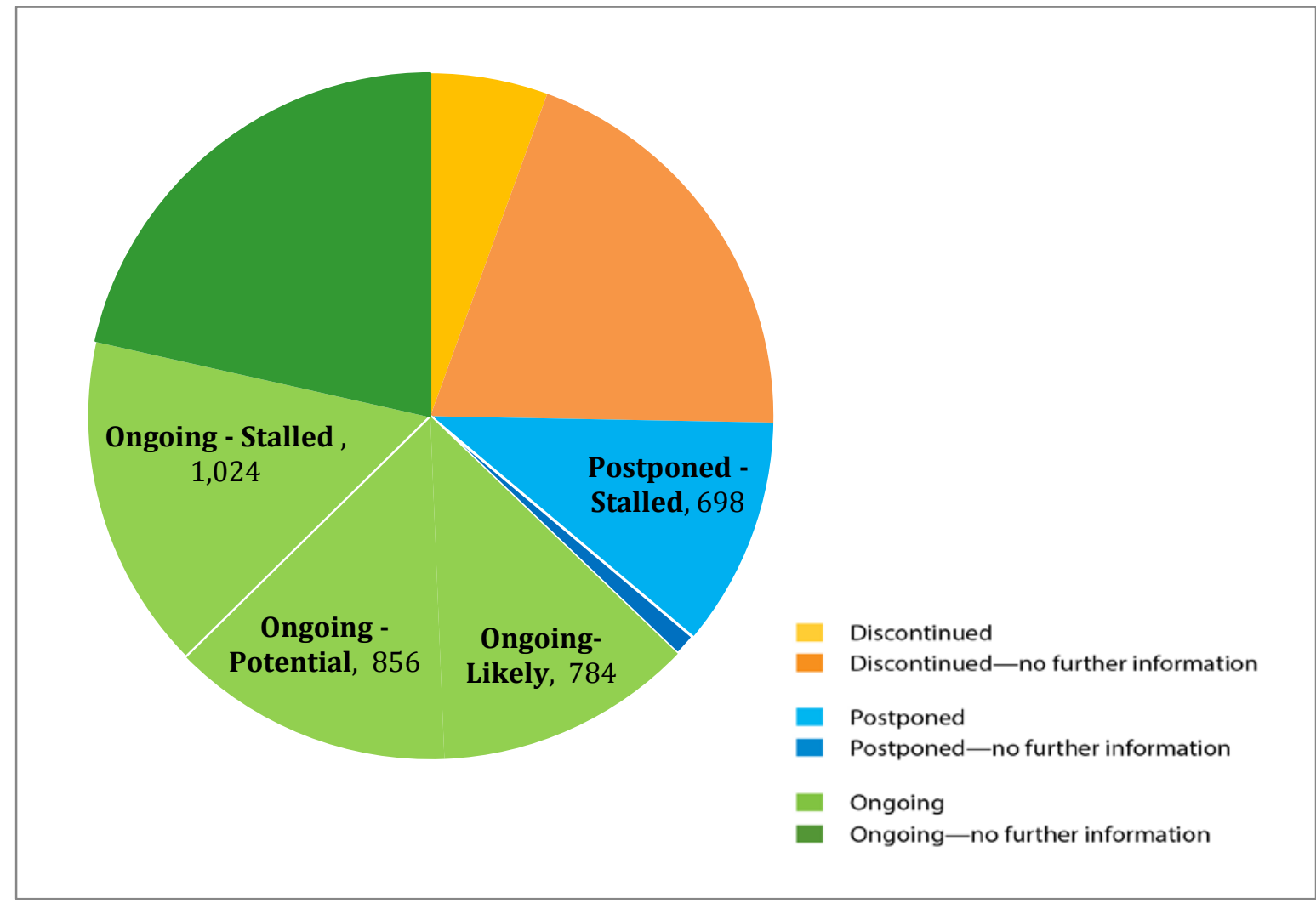

Figure ES-1. Breakdown of geothermal capacity listed as "in development" between 2012 and 2015, by current project status. Only projects with sufficient public information were included in this analysis (indicated by light green, light blue, and light orange colors). This pie chart shows the results: $784 \mathrm{MWe}$ are likely to come online by 2020, 856 MWe could potentially come online if small hurdles were overcome, and 1,722 MWe $(698+1,024)$ are currently stalled, but could come online if project barriers were removed. Other ongoing and postponed projects (indicated by dark green and dark blue) may also come online if barriers are removed, assuming they had similar barriers to those analyzed.

We investigated the 4,812 MWe of projects that are ongoing or postponed, but were limited in our final analysis to a subset of projects - our "sample dataset" - that had additional information to review $(3,362 \mathrm{MWe})$. Of these projects with public information, we found that $23 \%$ of these projects $(784 \mathrm{MWe}$ ) have no apparent barriers, and are likely to come online by 2020 - a significant increase in five years. This alone, however, is not enough to double geothermal capacity in the United States.

However, an additional $25 \%$ ( $855 \mathrm{MWe}$ ) of projects have the potential to come online if they overcome small hurdles. The remaining 51\% (1,024 MWe ongoing and $698 \mathrm{MWe}$ postponed) of projects examined are currently stalled due to larger barriers, but could come online with support in overcoming these barriers. The barriers found to be hindering these projects include 
financing, permitting, transmission, and acquisition of power purchase agreements (PPA). See Section 6 of this report for more information on barriers.

In addition to the $3.4 \mathrm{GWe}$ of projects analyzed, an additional $1.4 \mathrm{GWe}$ of ongoing and postponed projects did not have sufficient information for detailed analysis, but are likely to have similar barriers. Because these $4.8 \mathrm{GWe}$ (total) of geothermal are already in development, they are the first projects likely to be positively impacted by overcoming barriers - and would more than double geothermal capacity in the United States if deployed.

Industry suggests that, should projects face little to no hurdles, a geothermal project would take less than the typical $5+$ years to develop; they suggest a project could move through all stages of exploration and development in approximately three years (Glacial Partners 2009, Nordquist 2015). Therefore, overcoming these hurdles on an industry-wide level could allow for swifter deployment of geothermal - in other words, projects not yet begun could also be completed by the 2020 goal.

This analysis suggests that doubling geothermal electricity capacity in the United States is possible, but that it is unlikely to be achieved without assistance in overcoming barriers. Overcoming barriers on an industry-wide level could expedite and/or allow the continued development of 4,047 MWe of ongoing projects, $765 \mathrm{MWe}$ of postponed projects, and an additional 2,789 MWe of potential yet to be started - enough to triple the current installed geothermal capacity in the United States. Although not all of these projects will prove to be technically or economically viable, the analysis suggests that identifying and eliminating barriers related to permitting, financing, transmission, and acquisition of PPAs for geothermal projects could have a significant impact on the potential to double U.S. geothermal energy generation by 2020 . 


\section{Contents}

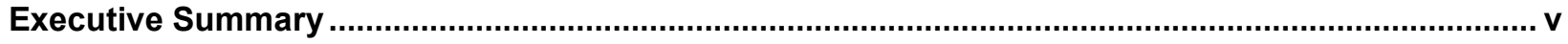

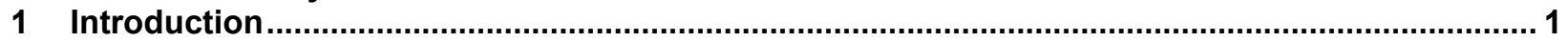

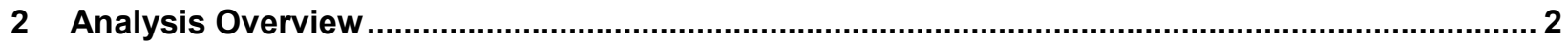

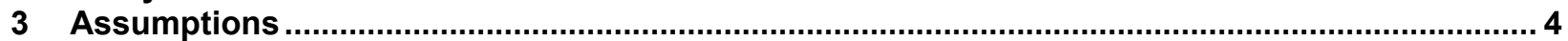

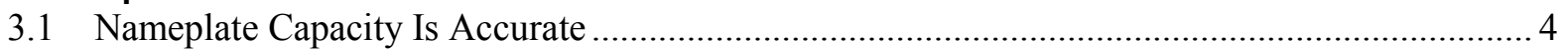

3.2 Current Sources Are Accurate.................................................................................

3.3 Discontinued Project Status Is Accurate ......................................................................

3.4 Planned Capacity Estimates Are Realistic and Accurate ...............................................5

3.5 Current Plants Will Operate at the Same Capacity .......................................................

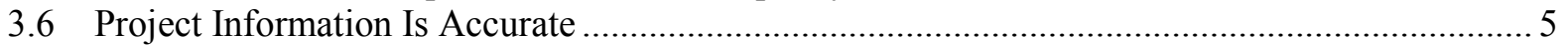

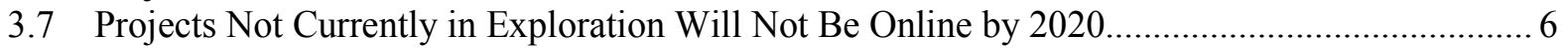

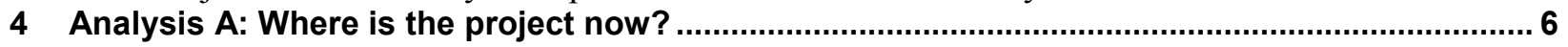

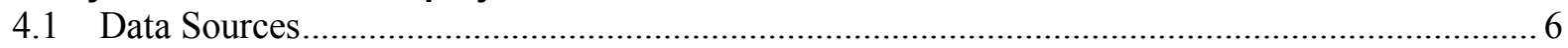

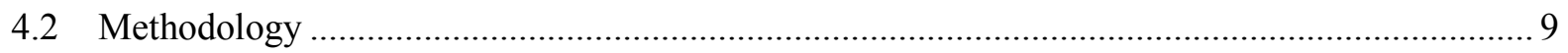

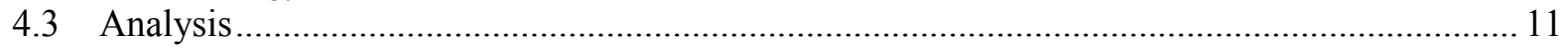

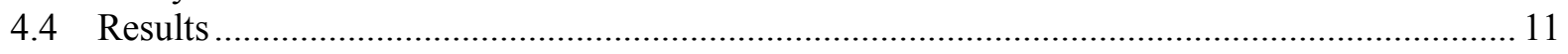

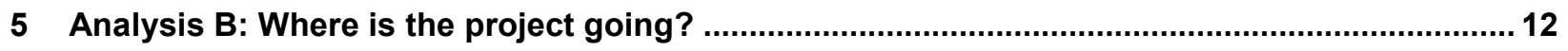

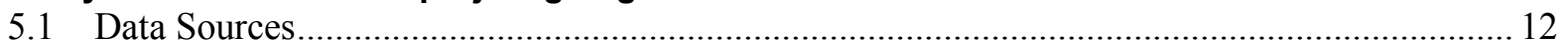

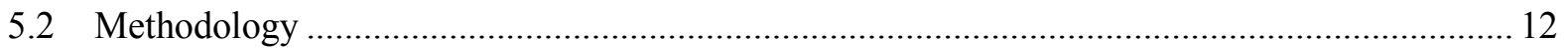

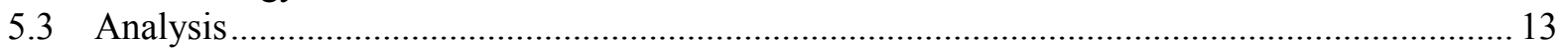

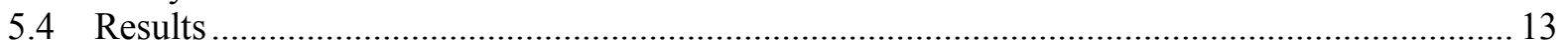

6 Analysis C: Will the project be completed by 2020 ? ............................................................. 15

6.1 Data Sources................................................................................................. 15

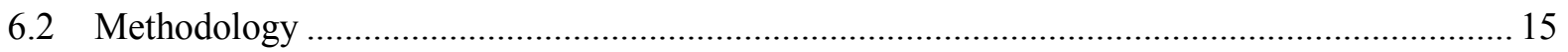

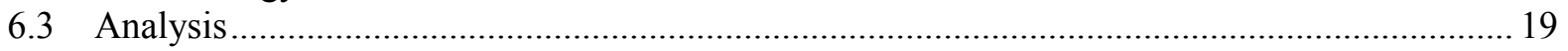

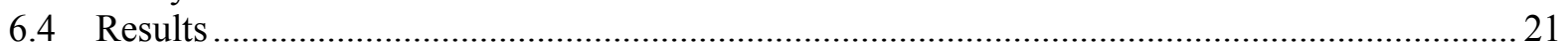

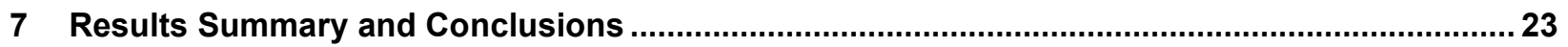

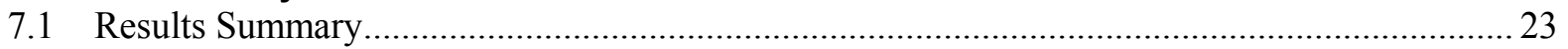

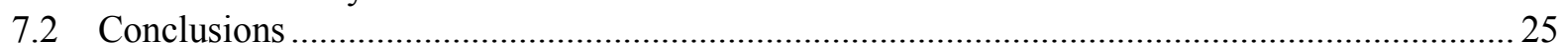

References .................................................................................................................................. 26

APPENDIX A: Comparison of Geothermal Nameplate and Summer Capacities ................................28 APPENDIX B: Analysis D: How Much Additional Geothermal Potential Energy Can be Deployed? 29

B.1 Data Sources ...................................................................................................... 29

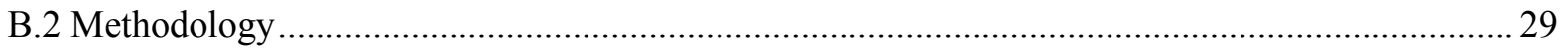

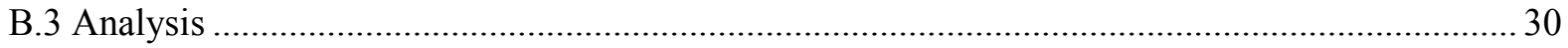

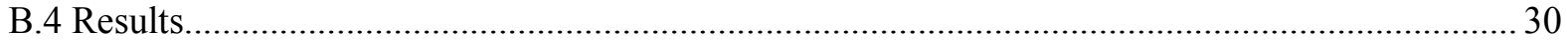




\section{List of Figures}

Figure ES-1. Breakdown of geothermal capacity listed as "in development" between 2012 and 2015, by current project status.

Figure 1. Recent United States geothermal installed nameplate capacity (MW) and annual generation (MWh). Nameplate capacity increased nearly 28\% between 2000 and 2013 (823 MW from $2,942 \mathrm{MW}$ to $3,765 \mathrm{MW}$ ) at an average annual growth rate of $2 \%$. For geothermal deployment to double by 2020 , capacity would have to increase an average of $10 \%$ per year between 2013 and 2020 ...

Figure 2. Map of United States geothermal regions. Geothermal regions were used in our analysis to understand the distribution of barriers and project delays. For example, the Gulf of California Rift Zone had a significant proportion of projects postponed and discontinued (see Figure 5). Source: Young et al. 2012.

Figure 3. Capacity of projects by GEA development phase (MWe). This figure shows the distribution of projects by phase for all projects $(6,641 \mathrm{MWe}$ total), including postponed projects and projects for which we had no information on development phase (labeled "unknown"). Over $65 \%$ of capacity was categorized as early stage development phases (Prospect and Phase I).

Figure 4. Project status analysis (2012-2015). Total Project Capacity Reviewed: 6,441 MWe. Nearly $75 \%$ of capacity is considered ongoing or postponed $(4,812 \mathrm{MWe})$, but only $70 \%$ of this ongoing and postponed capacity $(3,362 \mathrm{MW})$ had sufficient information for this analysis....... 14

Figure 5. United States geothermal total estimated project capacity (in megawatts) by geothermal region (2012-2015). This figure highlights areas that had significant proportions of projects that were either discontinued or postponed: Idaho Batholith (100\%), Gulf of California Rift Zone (77\%), Alaska (45\%), Northwest Basin and Range (47\%), the Walker-Lane Transition Zone (44\%), and the Northern Basin and Range (36\%).

Figure 6. Total project capacity reviewed $(6,441 \mathrm{MWe})$. Updated from Figure 4 to show portion of ongoing projects that are likely, potential and stalled, per Analysis C. The majority of project capacity reviewed is categorized as stalled $(51 \%)$. Postponed projects were found to be stalled because research does not indicate a likelihood for development to resume to achieve the 2020 goal.

Figure A1. Comparison of Nameplate to Net Summer Capacity, 1990-2013. Figure shows current discrepancy between installed nameplate capacity (design output of installed projects) to net summer capacity (net output of geothermal power available for sale during the summer). As of 2013, EIA survey data from geothermal generators shows that geothermal nameplate capacity was $3,765 \mathrm{MW}$ in comparison to 2,607 MW reported net summer capacity. Sources: Energy Information Association (2015) Nameplate Capacity: Form 860 Generator Data, State Electricity Profiles (July 2015). Summer Capacity: Annual Energy Review (2015). 


\section{List of Tables}

Table 1. Project Analyses. Three analyses were conducted on each project to determine: 1) where the project is now, 2) where the project is going, and 3) if the project will be completed by 2020. For each of these analyses, a discrete set of categories was allowed.

Table 2. GEA-defined Reporting Terms and Definitions. GEA annually asks organizations to indicate each project's stage of development. Each project must meet certain criteria to be considered and reported by the GEA as being in a respective phase of development. GEA's goal in developing these definitions was to increase the consistency, accuracy, and reliability of industry information.

Table 3. Comparison of Data Elements Collected from Third-Party Databases, by Source. Note for some SNL data fields, there is not a comparable data field in the GEA dataset.

Table 4. Categories and Definitions of Project Development Barriers. Sub-categories of financing, permitting, and resource barriers developed from a review of project data.............................. 18

Table 5. Primary Project Barriers by Phase of Development (Capacity in MWe). Major barriers at each stage are indicated in orange. Financing barriers affect the majority of capacity in Prospect, Phase I, and Phase II and permitting barriers affect the majority of capacity in Phase III.

Table 6. Categories and Definitions of Project Strategic Viability. Categories are qualitatively assigned based on the combination of a project's barriers and development progress.

Table 7. Projected Capacity, in Megawatts, of Ongoing or Proposed Projects. Financing is the greatest barrier for both stalled and potential projects. ............................................................ 22

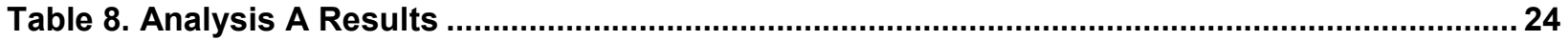

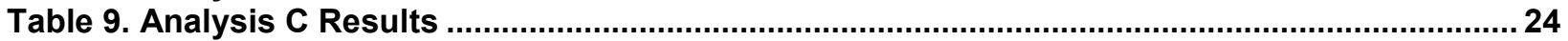

Table B1. Top Resource Areas for Geothermal Development. Of the 11 reviewed, 5 areas have operational capacity online. Seven areas would have additional capacity remaining for development if current projects are completed. 


\section{Introduction}

The President's Climate Action Plan makes a priority of doubling renewable energy generation by 2020 . As part of the plan, President Obama signed a memorandum in 2013 directing the federal government to consume $20 \%$ of its electricity from renewable sources by 2020 (Executive Office of the President 2013b).

Geothermal energy has the potential to play an important role in contributing to goals of producing more electricity from renewable sources in the United States. If the doubling goal were applied to geothermal, nameplate geothermal power generation capacity would need to increase from approximately $3.8 \mathrm{GWe}$ today to $7.6 \mathrm{GWe}$ by 2020 .

\section{The President's Climate Action Plan}

Double renewable energy generation by 2020 by:

- Expanding clean energy use

- Accelerating clean energy permitting

- Expanding and modernizing the electric grid

- Unlocking long-term investment in clean energy innovation.

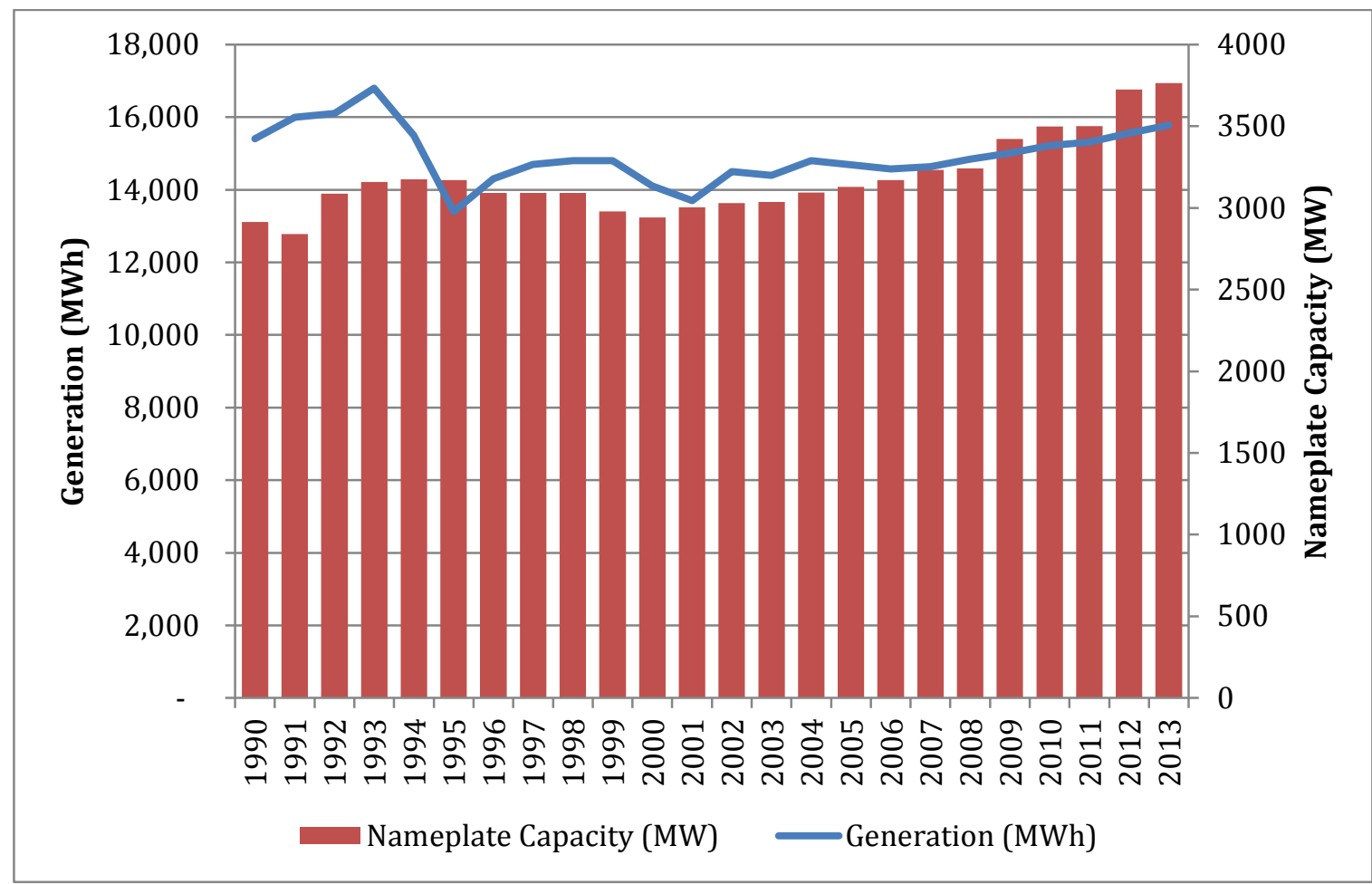

Figure 1. Recent United States geothermal installed nameplate capacity (MW) and annual generation (MWh). Nameplate capacity increased nearly 28\% between 2000 and 2013 (823 MW from 2,942 MW to 3,765 MW) at an average annual growth rate of $2 \%$. For geothermal deployment to double by 2020 , capacity would have to increase an average of 10\% per year between 2013 and 2020. Generation data source: State Electricity Profiles, July 2015 (EIA 2015). Nameplate capacity data source: EIA Form 860 in Electric Power Monthly, June 2015 (EIA 2015). See Appendix A for comparison of nameplate and net summer capacity. 
Doubling geothermal power generation by 2020 could pose a challenge, however, because geothermal power plants can take anywhere from 5 to 10 years to build under current conditions. In addition, only $600 \mathrm{MW}$ of geothermal energy has come online in the last 8 years (of available data, Figure 1, 2006-2013) to increase deployment above $3 \mathrm{GW}$.

The U.S. Department of Energy's Geothermal Technologies Office (GTO) directed the National Renewable Energy Laboratory (NREL) to conduct a strategic analysis centered on these questions:

- What is the status of current geothermal projects in development?

- What percentage of these projects is most likely to come online by 2020 ?

- What factors are holding up development?

- How can GTO expedite development?

The NREL Analysis Team collected information about current and potential United States geothermal projects to determine the feasibility of doubling geothermal capacity in addressing the President's Climate Action Plan goals.

We reviewed 230 geothermal projects (totaling 6,441 MWe) that were announced as "in development" in the last four years to identify the projects most likely to advance the doubling effort. We catalogued the potential capacity of projects that have been discontinued or postponed, but only considered projects in progress (i.e. not discontinued) as having the ability to contribute to the near-term supply of geothermal power. For these projects, this analysis identified the types and pervasiveness of barriers to development, including conclusions on the availability of adequate resources for commercial production, considering factors such as the geographic distribution and maturity of exploration to date.

This report documents the analytical methods we used to examine the viability of doubling geothermal energy production by 2020 .

\section{Analysis Overview}

We used publicly available data from the following sources to identify the technical and market barriers and projected capacity that could contribute to doubling nameplate geothermal generation capacity from 3,765 MWe to 7,530 MWe by 2020:

- Geothermal Energy Association (GEA) annual reports on geothermal power production and development in the United States (GEA 2015, 2014, 2013, 2012)

- Bureau of Land Management (BLM) permit and National Environmental Policy Act (NEPA) document records

- $\quad$ SNL Financial power plant database (SNL Financial 2014)

- Company websites

- Public company financial reports (Securities and Exchange Commission (SEC) 10-K filings). 
From these sources, we determined which projects might come online by 2020 with no federal intervention. We also identified resources and individual projects currently under development that might be encountering barriers that are slowing development.

We conducted the following four analyses:

- Analysis A: Where is the project now?

- Analysis B: Where is the project going?

- Analysis C: Will the project be completed by 2020?

- Analysis D: How much additional geothermal potential can be deployed?

In Analysis $\mathrm{A}, \mathrm{B}$, and $\mathrm{C}$ we focused on projects in development to determine which projects might come online by 2020 (Table 1).

In Analysis D, we reviewed the top geothermal resource potential areas in the United States to see how much additional potential could be deployed. We used projects in development in those areas to suggest what barriers developers might face if they try to develop additional potential in these areas. Overcoming barriers has the potential to make this additional geothermal potential more attractive to developers. Because these projects are not likely to come online by 2020 , this analysis is included only as an appendix (Appendix B) to this report. 
Table 1. Project Analyses. Three analyses were conducted on each project to determine: 1) where the project is now, 2) where the project is going, and 3) if the project will be completed by 2020 . For each of these analyses, a discrete set of categories was allowed.

\begin{tabular}{|c|c|c|c|}
\hline \multicolumn{2}{|c|}{ Analyses } & Categories & Description \\
\hline \multirow{5}{*}{$\begin{array}{l}\text { Analysis A: } \\
\text { Where is the } \\
\text { project now? }\end{array}$} & \multirow{5}{*}{$\begin{array}{l}\text { Project } \\
\text { Development } \\
\text { Phase }^{\mathrm{a}}\end{array}$} & Prospect & Regional reconnaissance \\
\hline & & Phase I & Resource procurement and identification \\
\hline & & Phase II & Resource exploration and confirmation \\
\hline & & Phase III & Permitting and initial development \\
\hline & & Phase IV & Resource production and power plant construction \\
\hline \multirow{3}{*}{$\begin{array}{l}\text { Analysis B: } \\
\text { Where is the } \\
\text { project going? }\end{array}$} & \multirow{3}{*}{ Project Status $^{b}$} & Ongoing & Projects currently in development \\
\hline & & Postponed & $\begin{array}{l}\text { Projects no longer in development but with the } \\
\text { intention of resuming exploration }\end{array}$ \\
\hline & & Discontinued & $\begin{array}{l}\text { Projects no longer in development with no intention } \\
\text { of resuming exploration }\end{array}$ \\
\hline \multirow{4}{*}{$\begin{array}{l}\text { Analysis C: Will } \\
\text { the project be } \\
\text { completed by } \\
2020 ?\end{array}$} & \multirow{4}{*}{$\begin{array}{l}\text { Strategic } \\
\text { Viability }\end{array}$} & Likely & $\begin{array}{l}\text { On track to come online by } 2020 \text { given current and } \\
\text { past progress (assuming no new hurdles) }\end{array}$ \\
\hline & & Potential & $\begin{array}{l}\text { Additional effort required to advance exploration } \\
\text { and development to come online by } 2020 \text { (i.e., } \\
\text { current barriers and/or lack of project progress) }\end{array}$ \\
\hline & & Stalled & $\begin{array}{l}\text { Exploration and/or development significantly } \\
\text { slowed or stalled for a cause unrelated to resource } \\
\text { availability }\end{array}$ \\
\hline & & Pre-development & No on-site activities to date \\
\hline
\end{tabular}

${ }^{a}$ Based on GEA report data and verified through review of publicly available documents (news articles, company websites, and regulatory permits); ${ }^{\mathrm{b}}$ Based on SNL Financial data and verified through review of publicly available documents (news articles, company websites, and regulatory permits); ${ }^{\mathrm{c}}$ NREL designation.

\section{Assumptions}

\subsection{Nameplate Capacity Is Accurate}

Our analysis did not adjust or verify nameplate capacity of geothermal sites currently online. We assumed that the unit and plant data reported by the Energy Information Administration (EIA) in Form 860 are reliable and up to date. This analysis did not construct or calculate estimates of resource capacity or planned capacity from primary scientific or operations data.

\subsection{Current Sources Are Accurate}

We assumed that the unique set of projects from SNL Financial and GEA is representative of all projects currently in development in the United States. We submitted requests to the top 11 geothermal developers to verify the accuracy of this data, representing $60 \%$ of our project list. Four developers responded. While we conducted research to verify these projects, we did not 
conduct additional searches to identify any projects that these third-party sources might have overlooked.

\subsection{Discontinued Project Status Is Accurate}

Our review of the information collected revealed that some projects in development in 2012 had been discontinued before or during 2015. If a project did not exist in the GEA annual report in 2015 and was marked as "discontinued" by SNL Financial, we assumed that the consistent response between sources was sufficient verification that the project was closed. We did no further analysis on the barriers for these projects.

\subsection{Planned Capacity Estimates Are Realistic and Accurate}

We assumed that reported planned capacity estimates were realistic, and did not independently verify these estimates. We did not review geological studies and exploration data sets to confirm or deny the likelihood that the planned capacity would be achieved. Consequently, our analysis does not identify or include the uncertainty associated with using the planned capacity.

We also assumed that the most recent assessments of planned capacity available through GEA, SNL Financial, and/or company reports are estimates of the likely capacity that might be developed by 2020 . The majority of projects we reviewed have planned capacity estimates equivalent to the resource capacity identified. We used resource capacity estimates (i.e., assessments of the total potential of the area that could be developed) only as approximations, and only when planned capacity estimates were not available.

\subsection{Current Plants Will Operate at the Same Capacity}

We assumed that current geothermal plants will continue to operate at the same capacity through at least 2020 and that no generators will be decommissioned. That means that all new projects under development would contribute to the doubling goal instead of replacing current generation. This assumption may be unrealistic because of the inevitable resource degradation over the production lifetime of a geothermal facility. Future iterations of this analysis could incorporate corrections with a review of the production histories of these plants.

\subsection{Project Information Is Accurate}

We assumed that the publicly available information we found for the projects for this report form a representative sample of all geothermal project barriers and progress. This assumption may not adequately address issues for private developers for whom little to no information is available on current project status. We reached out to the top 11 project developers representing nearly 3,598 MW to verify project information as of August 2015, and received feedback from companies covering over $887 \mathrm{MWe}$ of projects in all stages of development (i.e. ongoing, postponed, and discontinued). Developers who responded verified at least project status and capacity on all projects requested. For some projects, only the information in GEA's industry survey was available.

Relying on publicly available information may overstate the barriers of historically problematic projects. These projects may now be moving forward without additional issues. 
Over half (55\%) of the project capacity in our sample dataset was in the early stages of development (Prospect and Phase I). Confidence in the availability of the geothermal resource is typically not known until later phases of development. Therefore, for these projects, resource commerciality could still become a barrier to project development (if it is not already indicated).

\subsection{Projects Not Currently in Exploration Will Not Be Online by 2020}

In developing the criteria to determine viability for development by 2020 , we assumed that projects require a minimum of five years from the time they are identified as a prospect to the time they come online. This timeline is consistent with current patterns in the geothermal industry (e.g., Flóvenz 2013; Glacier Partners 2009), and does not consider the additional time for possible project delays. However, this may be an underestimate of potential capacity online should projects face little to no hurdles, in which case projects could move through all stages of development in approximately 3 years (Glacial Partners 2009, Nordquist 2015).

\section{Analysis A: Where is the project now?}

\subsection{Data Sources}

We used the GEA reporting terms as the primary method to define the project development phase (GEA 2010), as outlined in Table 2. 
Table 2. GEA-defined Reporting Terms and Definitions. GEA annually asks organizations to indicate each project's stage of development. Each project must meet certain criteria to be considered and reported by the GEA as being in a respective phase of development. GEA's goal in developing these definitions was to increase the consistency, accuracy, and reliability of industry information.

\begin{tabular}{|c|c|c|c|c|}
\hline Phase & Title & Resource Development & $\begin{array}{l}\text { Transmission } \\
\text { Development }\end{array}$ & External Development \\
\hline Prospect & $\begin{array}{l}\text { Regional } \\
\text { reconnaissance }\end{array}$ & $\begin{array}{l}\text { Not yet meeting phase I } \\
\text { criteria }\end{array}$ & $\begin{array}{l}\text { Not yet meeting phase I } \\
\text { criteria }\end{array}$ & $\begin{array}{l}\text { Not yet meeting phase I } \\
\text { criteria }\end{array}$ \\
\hline Phase I & $\begin{array}{l}\text { Resource } \\
\text { procurement } \\
\text { and } \\
\text { identification }\end{array}$ & $\begin{array}{l}\text { At least } 2 \text { of the following: } \\
\text { - Literature survey } \\
\text { complete } \\
\text { - Geologic mapping } \\
\text { completed, Geophysical } \\
\text { and geochemical sample } \\
\text { sites identified } \\
\text { - Geochemical and } \\
\text { geophysical surveys in } \\
\text { progress }\end{array}$ & $\begin{array}{l}\text { Internal transmission } \\
\text { analysis complete }\end{array}$ & $\begin{array}{l}\text { All of the following: } \\
\text { - Land or lease } \\
\text { acquired } \\
\text { - Permitting process for } \\
\text { exploration drilling } \\
\text { (TGH and/or slim } \\
\text { holes) under way }\end{array}$ \\
\hline Phase II & $\begin{array}{l}\text { Resource } \\
\text { exploration and } \\
\text { confirmation }\end{array}$ & $\begin{array}{l}\text { At least } 1 \text { of the following: } \\
\text { - Temperature gradient } \\
\text { holes (TGH) drilled } \\
\text { - Slim hole drilled } \\
\text { - One full-size discovery } \\
\text { well drilled }\end{array}$ & $\begin{array}{l}\text { At least } 1 \text { of the following: } \\
\text { - Interconnection } \\
\text { application submitted } \\
\text { and queue position } \\
\text { established } \\
\text { - Transmission feasibility } \\
\text { studies under way }\end{array}$ & $\begin{array}{l}\text { At least } 1 \text { of the } \\
\text { following: } \\
\text { - Permit for slim hold } \\
\text { drilling applied for or } \\
\text { approved } \\
\text { - Permit for production } \\
\text { well drilling applied } \\
\text { for or approved }\end{array}$ \\
\hline Phase III & $\begin{array}{l}\text { Permitting and } \\
\text { initial } \\
\text { development }\end{array}$ & $\begin{array}{l}\text { At least } 2 \text { of the following: } \\
\text { - At least one full-size } \\
\text { production well drilled } \\
\text { and operational } \\
\text { - At least one full-size } \\
\text { injection well drilled and } \\
\text { operational } \\
\text { - Reservoir } \\
\text { characterization } \\
\text { completed and } \\
\text { sustainable reservoir } \\
\text { capacity determined }\end{array}$ & $\begin{array}{l}\text { At least } 2 \text { of the following: } \\
\text { - Interconnection } \\
\text { feasibility study } \\
\text { complete } \\
\text { - System impact study } \\
\text { under way or complete } \\
\text { - Interconnection facility } \\
\text { - } \text { study under way } \\
\text { request submitted }\end{array}$ & $\begin{array}{l}\text { At least } 2 \text { of the } \\
\text { following: } \\
\text { - Plant permit } \\
\text { application complete } \\
\text { or in process } \\
\text { - Power purchase } \\
\text { agreement secured or } \\
\text { in negotiation } \\
\text { - Financing secured, or } \\
\text { being secured, for } \\
\text { portion of project } \\
\text { construction }\end{array}$ \\
\hline Phase IV & $\begin{array}{l}\text { Resource } \\
\text { production and } \\
\text { power plant } \\
\text { construction }\end{array}$ & $\begin{array}{l}\text { At least } 2 \text { of the following: } \\
\text { - Plant equipment on } \\
\text { order } \\
\text { - Plant construction under } \\
\text { way } \\
\text { - Production and injection } \\
\text { drilling under way }\end{array}$ & $\begin{array}{l}\text { All of the following: } \\
\text { - Interconnection } \\
\text { agreement signed } \\
\text { - Transmission system } \\
\text { service request studies } \\
\text { completed }\end{array}$ & $\begin{array}{l}\text { All of the following: } \\
\text { - Plant permit(s) } \\
\text { approved } \\
\text { - Engineering, } \\
\text { procurement, and } \\
\text { construction contract } \\
\text { signed } \\
\text { - PPA secured }\end{array}$ \\
\hline
\end{tabular}

Source: GEA 2010 
The GEA publishes a United States project list each year from company-reported survey results, supported by a review of publicly available documents such as news articles, company websites, and regulatory permits (GEA 2015, 2014, 2013, 2012). We reviewed geothermal projects in development in years 2012 through 2015 in order to evaluate a larger sample size of projects than would be available in a study of only the most current reports. Table 3 lists and compares the data collected from the GEA reports and the SNL Financial database, and identifies where the data elements were used in this analysis. As shown, we compiled project data related to anticipated capacity, location, status, and ownership.

Table 3. Comparison of Data Elements Collected from Third-Party Databases, by Source. Note for some SNL data fields, there is not a comparable data field in the GEA dataset.

\begin{tabular}{|l|l|l|}
\hline $\begin{array}{l}\text { Used in This } \\
\text { Analysis }\end{array}$ & $\begin{array}{l}\text { GEA Annual Reports } \\
\text { Data Fields }\end{array}$ & $\begin{array}{l}\text { SNL Financial Power Plant } \\
\text { Database Data Fields }\end{array}$ \\
\hline \hline \multirow{4}{*}{$\begin{array}{l}\text { General } \\
\text { characteristics }\end{array}$} & Project name & Project name \\
\cline { 2 - 3 } & Location (state, county) & Location (state, county, and GPS coordinates) \\
\cline { 2 - 3 } & $\begin{array}{l}\text { Resource and planned capacity (in } \\
\text { megawatts) }\end{array}$ & Planned capacity (in megawatts) \\
\hline \hline \multirow{3}{*}{ Project status } & Project phase & Project development phase \\
\cline { 2 - 3 } & & Project status \\
\cline { 2 - 3 } & Year report issued & Last date verified \\
\hline \hline \multirow{5}{*}{ viability } & Developer name(s) & Developer name(s) \\
\cline { 2 - 3 } & Owner name(s) & Owner name(s) and \% of ownership \\
\cline { 2 - 3 } & & Operator name(s) \\
\cline { 2 - 3 } & & Ultimate parent name(s) and \% of ownership \\
\cline { 2 - 3 } & & $\begin{array}{l}\text { Dates of asset sales (i.e., merger and acquisition } \\
\text { activity) }\end{array}$ \\
\cline { 2 - 3 } & & Date of PPA \\
\cline { 2 - 3 } & & Date to come online \\
\cline { 2 - 3 } & &
\end{tabular}

When projects were listed by both GEA and SNL, we compared project development phases from the GEA reports to data from SNL Financial to identify any major discrepancies. We also used news and financial reports on project development, along with permitting documents, to confirm or modify the project status. We determined that company financial reports were the most credible source for categorizing project progress. 


\subsection{Methodology}

\subsubsection{Creating Universal Records}

The first step was for us to create a unique list of geothermal projects under development and their characteristics. We compared projects on the basis of location, developer, owner, and estimated project size to confirm or deny whether listed records described the same project. Each original data element from SNL Financial and GEA was retained separately and marked "asreported data" for transparency between the original and unified records.

\subsubsection{Adding Data Elements}

We added project data on location, planned capacity, developer name, owner name, project phase, and project status from individual SNL Financial records and GEA reports into our unified data record. In the case of overlapping or similar elements, we used separate columns to keep data from each source transparent. We created a separate entry showing the data value we determined as most representative. In cases where there were conflicts (such as owner name), we gathered additional information using internet searches and SNL data to identify notices of asset acquisitions or sales and confirm the data.

\subsubsection{Physical Project Characteristics}

Our analysis relied on the geographic coordinates supplied by SNL Financial to identify the location of specific projects. In the GEA reports, project location information included only county and state. Based on the locations of projects listed in the GEA report, we collected specific information on these projects from company websites and reports, when available. We used the geothermal areas and regions listed in Open Energy Information (OpenEI 2014) to categorize projects by geography. The base set of geothermal areas used in OpenEI comes from the 253 geothermal areas identified by the U.S. Geological Survey (USGS) in its 2008 resource assessment (USGS 2008), but other sites have since been added through crowdsourcing.

\subsubsection{Determining the Project's Geothermal Region}

Using the coordinates listed by SNL Financial, we mapped projects in Geothermal Prospector ${ }^{1}$ with the "Exploration Regions" layer turned on (Figure 2). If the project did not have GPS coordinates but could be identified by city and/or county, we used these locations as an acceptable proxy for mapping purposes. The defined zone - an attribute of the layer-determined the geothermal region recorded.

\footnotetext{
${ }^{1}$ See http://maps.nrel.gov/gt_prospector for more information.
} 


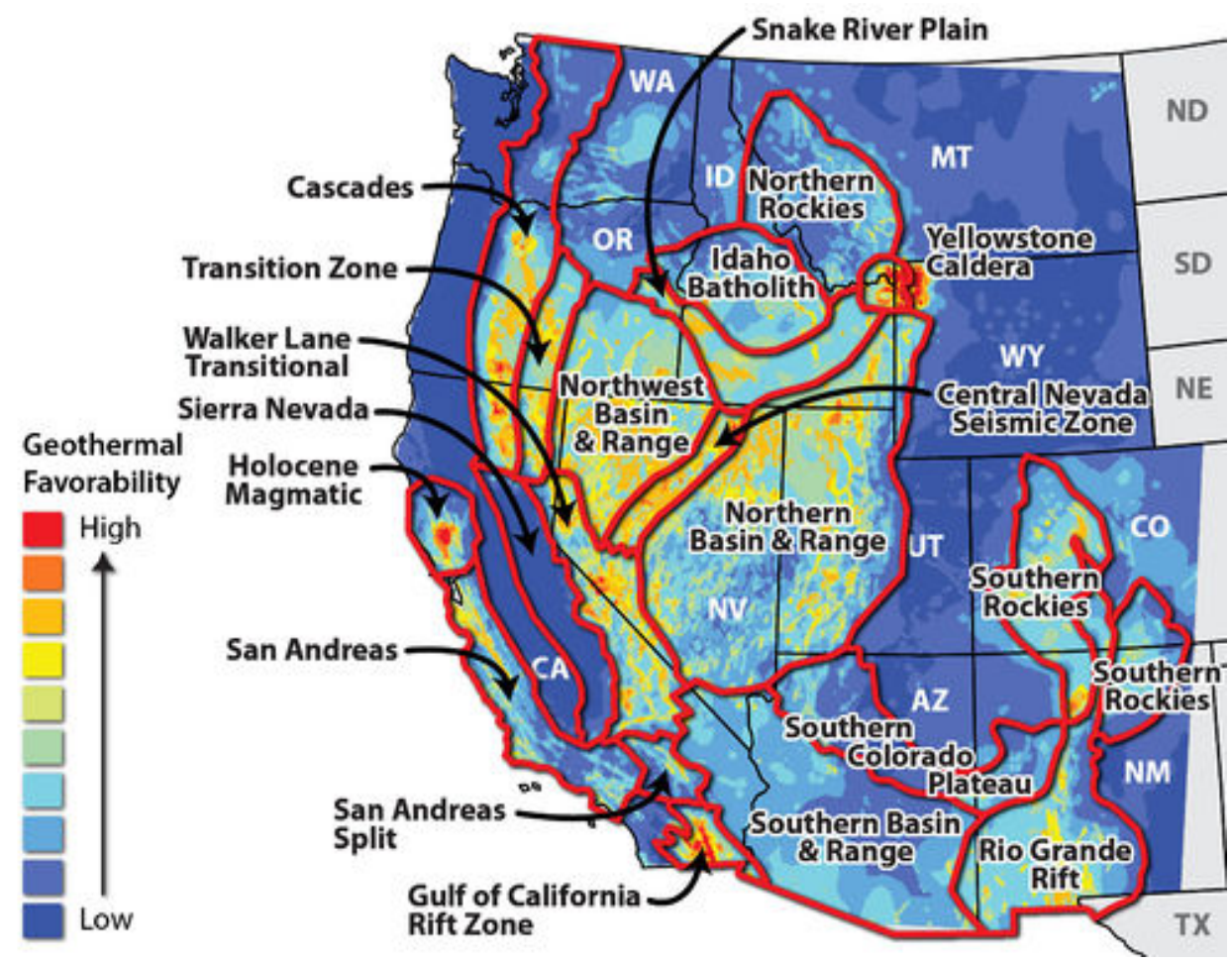

Figure 2. Map of United States geothermal regions. Geothermal regions were used in our analysis to understand the distribution of barriers and project delays. For example, the Gulf of California Rift Zone had a significant proportion of projects postponed and discontinued (see Figure 5). Source: Young et al. 2012.

If the project was not located within the bounds of an exploration region, it was listed as "not in defined region." If the project's approximate location would result in multiple conclusions (such as a county that spanned multiple regions or placed the project on a boundary) and no additional public information or maps could be found, the project's location was listed as "not available."

\subsubsection{Determining the Project's Geothermal Area}

Using the mapped location and exploration region in Geothermal Prospector, we compared the mapped geothermal areas in OpenEI to the project's location and selected the geothermal area that best encompassed the project. If the project was not located within the approximate bounds of the OpenEI geothermal areas, it was listed as "not in defined area."

\subsubsection{Resolving Conflicting Data}

In cases of conflicts (such as differences in listed ownership between GEA and SNL), we gathered additional information through internet searches and reviewed corporate notices and SNL data of asset acquisitions or sales. In situations where no further information could be found, we color-coded the elements in the spreadsheet to indicate uncertainty.

\subsubsection{Estimating Project Capacity}

SNL Financial reports planned capacity; GEA annual reports provide estimates of both the geothermal resource and planned capacity (in megawatts). We used the most recent assessments of planned capacity available through GEA, SNL Financial, and/or company reports as sources of the likely quantity of capacity in development. 
Although the majority of projects we reviewed specified planned capacity, we also found estimates of the total resource capacity. Because resource capacity estimates may overestimate near-term development by not reflecting the scale of the project, we used these estimates only when planned capacity estimates were not available. The outcome of our data preferences is that the capacity reported in this analysis is the most conservative estimate (i.e., smallest estimated capacity) of the resource's potential generation.

Of the 230 projects reviewed in this analysis, 84 did not have any form of estimated capacity. We recorded the estimated capacity of these projects as "not available." These projects were not included in possible capacity estimates.

\subsection{Analysis}

\subsubsection{Determining Project Development Phase}

Both SNL Financial and the GEA report portray development progress using their own classification systems. Since the geothermal industry is more familiar with the GEA phases, we used this classification. GEA phases have clearly identified criteria (Table 2), so we identified the GEA project phase that best characterized the project's research, transmission, permitting, and finance (GEA 2010). The reported GEA and SNL Financial project phases were used as a reference point, but we verified each project for the phase that best matched the publicly available information from agency and company websites, news sites, and financial reports. The reported GEA phase was used in 36 cases when public information was not sufficient to either verify or refute the GEA assessment.

\subsubsection{Determining Project Relevance}

Certain types of projects were removed from consideration in this analysis, regardless of project status. For example, enhanced geothermal systems demonstration projects at Brady and Desert Peak were considered research projects only per discussion with the developer, and were therefore removed from consideration; their potential does not represent capacity that would remain online. Projects labeled as a "repower" were also eliminated from consideration because these projects were intended to increase the generation - not capacity - at currently-installed facilities (Glacial Partners 2009, Nordquist 2015).

\subsection{Results}

Of the 230 total projects reviewed, only 9 projects (all discontinued) did not have sufficient information to determine the project development phase (at the time the project was discontinued). However, GEA development phases could be estimated for all ongoing and postponed projects.

Figure 3 shows the distribution of project phases across all projects. 2,228 MWe (35\% of projects) were in the prospect phase, 1,987 MWe (31\%) were in Phase I, 1,411 MWe (22\%) were in Phase II, 639 MWe (10\%) in Phase III, and 111 MWe (2\%) were in Phase IV. The remaining 65 MWe did not have sufficient information to determine development status. 


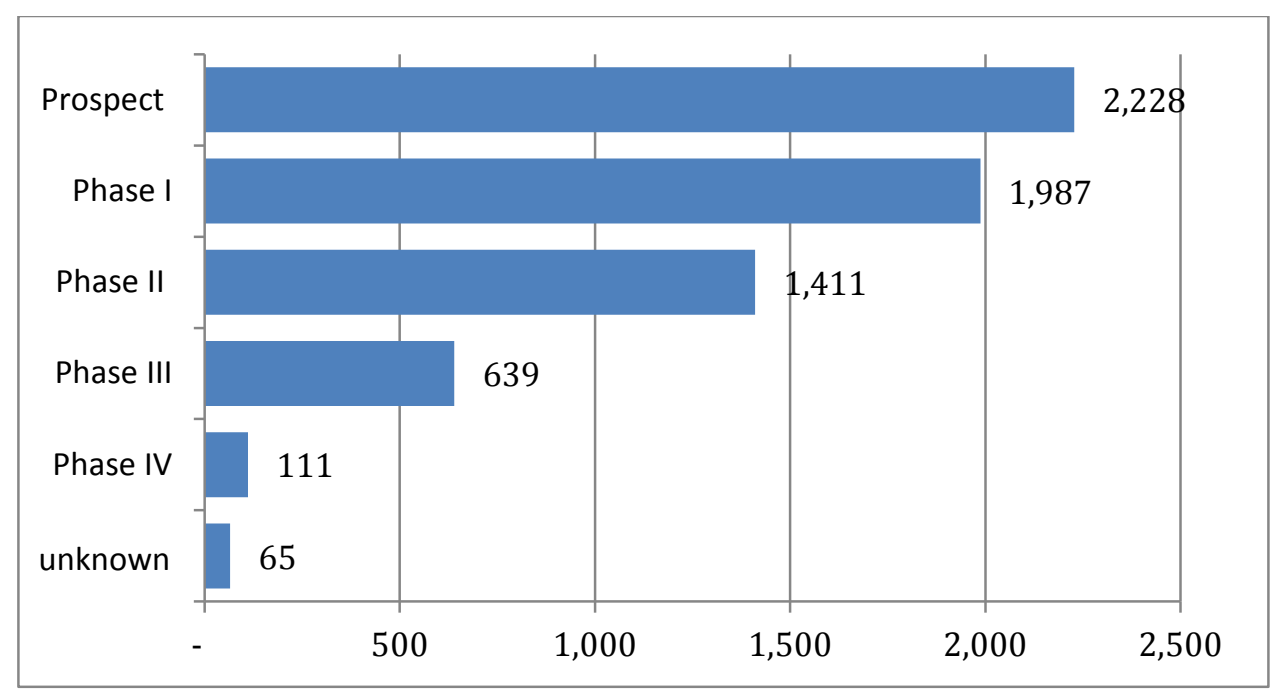

Figure 3. Capacity of projects by GEA development phase (MWe). This figure shows the distribution of projects by phase for all projects $(6,641 \mathrm{MWe}$ total), including postponed projects and projects for which we had no information on development phase (labeled "unknown"). Over $65 \%$ of capacity was categorized as early stage development phases (Prospect and Phase I).

\section{Analysis B: Where is the project going?}

\subsection{Data Sources}

We used SNL Financial (2014) data to assign project status to three categories: ongoing, postponed, or discontinued (Figure 4). SNL Financial also provided the date on which the project was last verified. We then used the existence or absence of project data in the GEA reports to verify this project status. In all cases, we confirmed or altered status based on news, company websites, and financial reports about project development. Because of the regulatory implications of false reporting, we determined that company financial reports, such as $10-\mathrm{Ks}$, were the most credible sources for project status verification.

\subsection{Methodology}

The projects we sourced from the GEA reports were designated ongoing, postponed, or discontinued using the following criteria:

- Ongoing projects are projects that are currently in development and were defined by these characteristics:

- Listed in the GEA annual report.

$\circ$ Listed as ongoing in the SNL Financial database.

- Postponed projects are projects that are no longer in development but were defined as having the intention to resume exploration at a later date:

○ Listed as postponed in the SNL Financial database. SNL reclassifies announced projects as "postponed" if the developer indicates plans to develop but has not performed any activity in the most recent 24-36 months.

$\circ$ Explicitly indicated as postponed in company filings or news announcements. 
- Discontinued projects are projects that are no longer in development and with no intention to resume exploration at a later date and classified "discontinued" when a project had both of the following characteristics:

- Previously listed in the GEA annual report but not given in the current year.

- Listed as discontinued in the SNL Financial database.

If project data were sourced only from SNL Financial, we listed the project status using their designations of ongoing, postponed, or discontinued.

Capacity that came online during the study period was removed, as it is no longer available project capacity for new generation.

\subsection{Analysis}

When possible, we performed additional research on publicly available information to verify project status. This research included searching agency sites to determine permitting status, along with searching owners' and developers' websites or financial reports. Of the 106 projects found in the SNL Financial database, 47 were categorized as discontinued. Fourteen projects did not have sufficient information to verify status.

When project data were sourced exclusively from GEA reports-particularly when a project was listed only once in the GEA annual reports in 2012 or 2013 and not listed in the 2014 report-we investigated further using publicly available sources. This research included searches of agency sites to determine permitting status, as well as searches of owner and developer websites or financial reports. Of the 118 projects in this study that were based exclusively on GEA data, only the status for 2 projects could not be verified because of the scarcity of available public information, and 31 projects were verified as having been discontinued.

\subsection{Results}

Figure 4 shows total estimated project capacity (in megawatts) and project status. For each status, we also distinguish between those projects for which there are publically available information, and those for which no additional information could be found.

In the years 2012 through 2015, 6,441 MWe of projects were started. Of those projects, 4,047 MWe are still active and another 2,394 MWe have been postponed or discontinued. The reasons for discontinuation are not formally consolidated in a single database, and were not researched as part of this effort.

For purposes of further analysis, our "sample dataset" (3,362 MWe) includes those projects that are postponed with additional information $(698 \mathrm{MWe})$ and those that are ongoing with additional information $(2,664 \mathrm{MWe})$. 


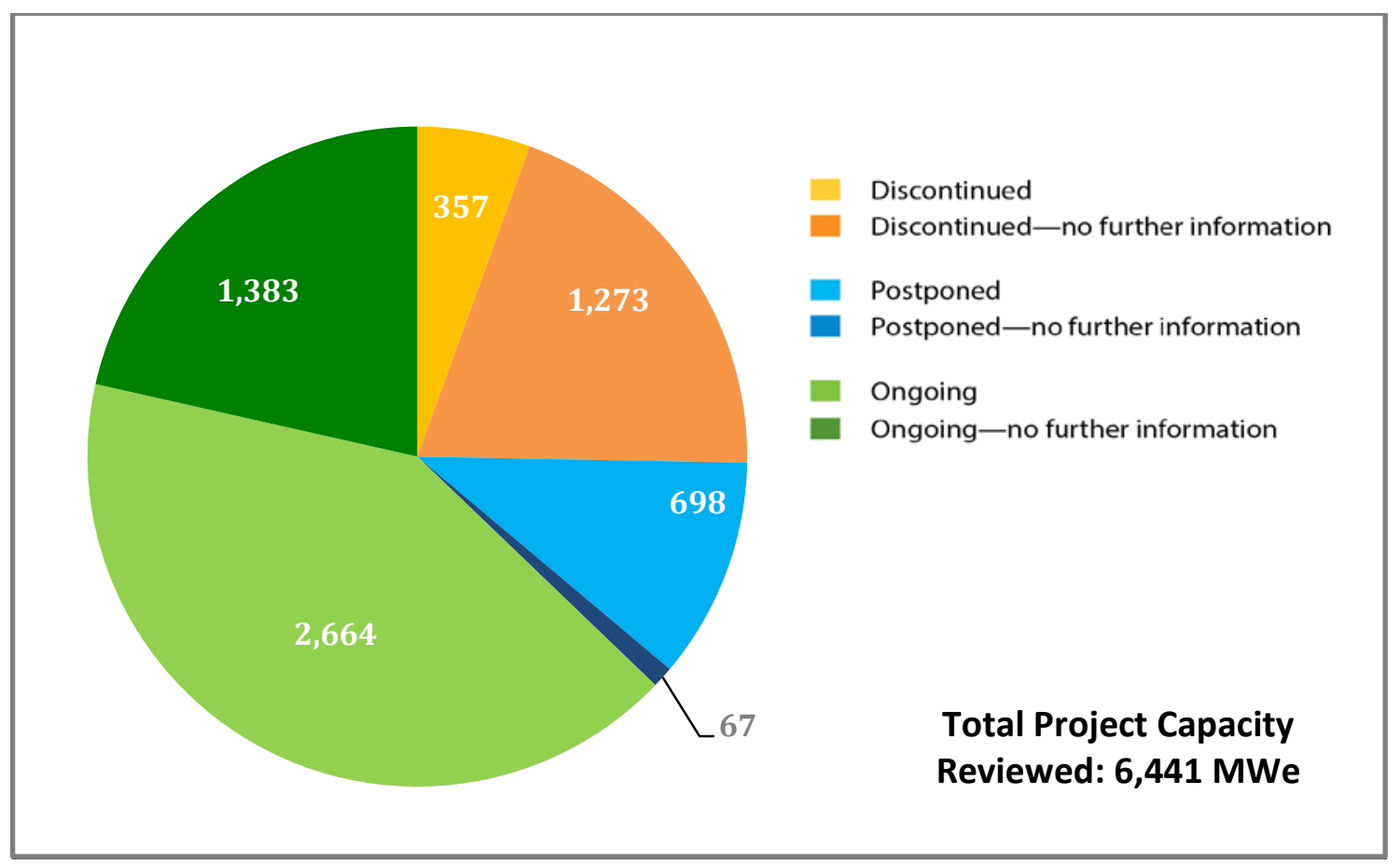

Figure 4. Project status analysis (2012-2015). Total Project Capacity Reviewed: 6,441 MWe. Nearly $75 \%$ of capacity is considered ongoing or postponed $(4,812 \mathrm{MWe})$, but only $70 \%$ of this ongoing and postponed capacity $(3,362 \mathrm{MW})$ had sufficient information for this analysis.

We categorized the full dataset (6,441 MWe) by geothermal region (Figure 5), which highlighted two geothermal regions that had a noteworthy portion of projects discontinued or postponed: the Northwest Basin and Range (parts of NV, OR, ID, CA) and the Gulf of California Rift Zone (southern $\mathrm{CA}$ ), which could indicate significant barriers in these regions. 


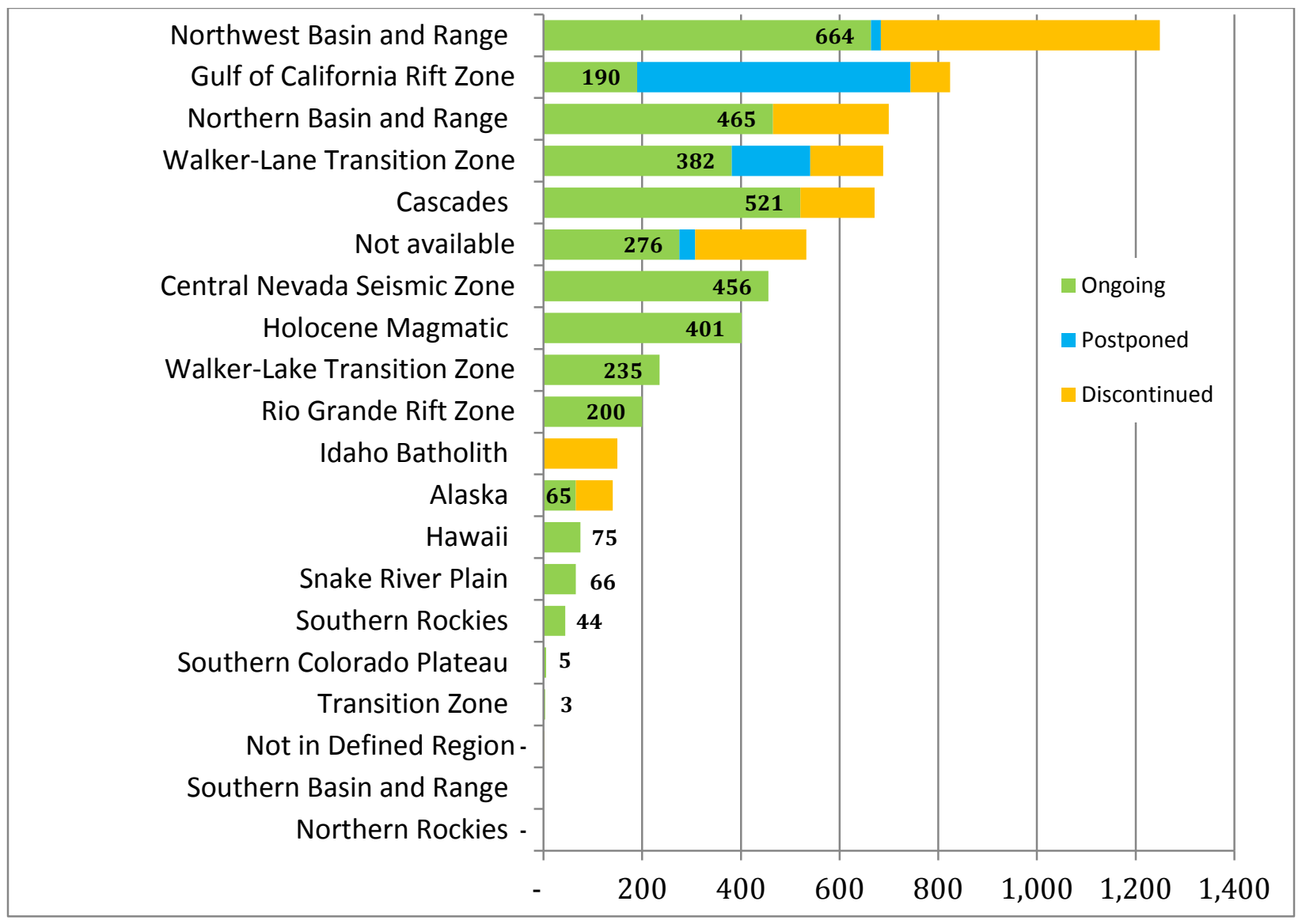

Figure 5. United States geothermal total estimated project capacity (in megawatts) by geothermal region (20122015). This figure highlights areas that had significant proportions of projects that were either discontinued or postponed: Idaho Batholith (100\%), Gulf of California Rift Zone (77\%), Alaska (45\%), Northwest Basin and Range (47\%), the Walker-Lane Transition Zone (44\%), and the Northern Basin and Range (36\%).

\section{Analysis C: Will the project be completed by 2020?}

\subsection{Data Sources}

We reviewed the following information sources to identify potential project barriers and the viability of the project coming online by 2020 :

- News stories on company activities, permitting progress, and/or litigation results

- Press releases on PPAs

- Asset purchases and divestitures

- Company and agency websites

- Financial reports

- Agency reports and permits when available.

\subsection{Methodology}

Since geothermal has a typically long development timeframe, we analyzed hurdles impeding geothermal development. To identify the project barriers, we performed the following: 
- Reviewed available financial disclosures

- Annual reports, company websites, and press releases were reviewed to identify the company's outlook and spending on the projects.

- Identified recent project ownership changes

- We used SNL Financial records of asset and company mergers and acquisitions to identify the dates of ownership changes and party names associated with the transactions. Press coverage research of sales revealed additional information on the assets or business direction that may have prompted the ownership changes. Records of both the previous owners and the new owners were included in this search to verify the change.

- Reviewed available permits and/or applications status

- The status of permits in the process of being issued by the BLM is not transparent to the general public. We did, however, approximate status through research on the BLM website that indicated the existence of National Environmental Policy Act (NEPA) documentation (such as environmental impact statements and environmental assessments). ${ }^{2}$ The context supporting these documents, as well as associated outcomes, was considered a reliable source to determine barriers associated with permitting.

- Identified trends or significant recent events in media coverage and/or litigation

- When information from company sources and/or state agencies was insufficient or unavailable, we performed Google searches to find recent news coverage and litigation results. When projects faced previous significant delays, we conducted additional research to determine whether these delays would be ongoing. We included only ongoing causes of delay or litigation in this analysis.

Using the sources described above, we identified development barriers causing project delays; however, explicitly identifying the cause of the delay was not always possible. For example, a press release might announce that a PPA had been canceled with no information about what triggered the cancellation. In these instances, we relied on our analysts' ability to interpret project activity from the publicly available information sources. In the example of a cancelled PPA, a developer may indicate they were unable to meet the PPA terms. The most supported conclusion was identified as a possible barrier.

When we identified more than one barrier affecting project progress, we labeled the one with the most impact as primary and those with lesser impact as secondary. These labels were the result of compiling information collected in the barrier research process and developing a cohesive "story" about a project. For example, if the most significant project barrier appeared to be finding parties to obtain a PPA, we listed the primary barrier as "financing-PPA acquisition." The secondary barrier was listed as "permitting-unspecified delays."

\footnotetext{
${ }^{2}$ See http://www.blm.gov/wo/st/en.html for more information. See also the geothermal NEPA database, http://en.openei.org/wiki/RAPID/NEPA
} 
Since the analysis focused on projects that could potentially come online by 2020 , we did not actively identify barriers on discontinued projects, but this information was recorded where readily available.

Although this analysis estimates the capacity of geothermal projects to come online by 2020 , future uncertainties and potential barriers may also affect project completion. This analysis considered only current barriers.

Because the primary analysis goal was to identify capacity for near-term development, we did not conduct an in-depth analysis of total possible resource potential available by area. This analysis may miss geographic areas with higher resource potential than those listed.

This analysis may over- or under-represent project progress to meet the 2020 doubling goal. Given the qualitative data sets, the method described here relies on our analysts' assessment of the severity of the development barrier and the project's likely progress in the next five years. Although each conclusion is based on multiple data sources, we assumed that the analysts' conclusions are objective, and the viability for development will not significantly change without external intervention.

Table 4 lists the various categories that were assigned to each project as "barriers" (i.e. sources of delay) to progress in the project's development. 
Table 4. Categories and Definitions of Project Development Barriers. Sub-categories of financing, permitting, and resource barriers developed from a review of project data.

\begin{tabular}{|c|c|}
\hline Barrier Category & Description \\
\hline No Information & Barriers to project development not identifiable because of lack of public data \\
\hline Technology Maturity & Technology demonstration; not a commercial power project \\
\hline Labor & $\begin{array}{l}\text { Delays or additional steps relating to union, labor contract, or other worker } \\
\text { unrest or disagreements; includes issues pertaining to finding adequate } \\
\text { qualified labor }\end{array}$ \\
\hline Legal & $\begin{array}{l}\text { Delays caused by the development of legal documentation outside of the } \\
\text { permitting process, such as contract negotiations and/or due diligence }\end{array}$ \\
\hline Construction & $\begin{array}{l}\text { Modifications to plant design, interruptions to development, and/or other } \\
\text { construction issues related to the plant developer or operator }\end{array}$ \\
\hline Transmission & $\begin{array}{l}\text { Lack of access to sufficient electricity transmission or barriers to transmission } \\
\text { development }\end{array}$ \\
\hline \multicolumn{2}{|l|}{ Financing } \\
\hline Access to capital & $\begin{array}{l}\text { Inadequate access to funding, delays in obtaining funding, negotiation of } \\
\text { royalties or fees, or other barriers related to the procurement of PPAs }\end{array}$ \\
\hline Capital budgeting & Business delays specific to the owner, developer, and/or operator \\
\hline Change in ownership & Ownership changes altering project progress (mergers and/or acquisitions) \\
\hline PPA acquisition & $\begin{array}{l}\text { Limitations related to the procurement and maintenance of PPAs, including } \\
\text { inability to secure a PPA or inability to meet PPA milestones }\end{array}$ \\
\hline \multicolumn{2}{|l|}{ Permitting } \\
\hline Unspecified delays & Approvals and/or submissions of permits delayed for unspecified reasons \\
\hline Community & $\begin{array}{l}\text { Community backlash and/or disagreement with development; NIMBY } \\
\text { concerns }\end{array}$ \\
\hline Environmental & $\begin{array}{l}\text { Concerns by agencies and tribal entities relating to environmental quality or } \\
\text { environmental impact }\end{array}$ \\
\hline Cultural & Potential delays resulting from site-specific concerns raised by tribal entities \\
\hline \multicolumn{2}{|l|}{ Resource } \\
\hline Access & $\begin{array}{l}\text { Topography, other geographical, and/or geological constraints to accessing } \\
\text { the geothermal resource that prohibits exploration }\end{array}$ \\
\hline Economics & $\begin{array}{l}\text { Resource determined not to be commercially viable for further development } \\
\text { at the time }\end{array}$ \\
\hline Uncertainty & $\begin{array}{l}\text { Need for additional resource characterization, such as concerns for dry or } \\
\text { unproductive wells }\end{array}$ \\
\hline
\end{tabular}




\subsubsection{Identifying Insufficient Information}

In all phases of data collection, we marked projects "no information available" when we exhausted all sources of public information without finding information on, or current status of, the project. Public disclosure is characteristically absent on small privately owned projects. We also marked projects "no information available" however, when they were identified as under development but did not have recent or detailed public information or coverage to support a conclusion on project barriers or viability. Some projects were excluded because of our standard of requiring cited sources to determine project barriers and viability.

\subsection{Analysis}

\subsubsection{Analyzing Barriers by Phase of Development}

The projected capacity and project development phase (data from SNL Financial and GEA reports) and the primary project barriers are itemized in Table 5 . The major barrier for each phase of development is highlighted. The largest project capacity at each phase is defined by these barrier categories:

- Prospect: PPA acquisition

- Phase I: access to capital

- Phase II: capital budgeting

- Phase III: permitting. 
Table 5. Primary Project Barriers by Phase of Development (Capacity in MWe; Number of Projects in parenthesis). Major barriers at each stage are indicated in orange. Financing barriers affect the majority of capacity in Prospect, Phase I, and Phase II and permitting barriers affect the majority of capacity in

Phase III.

\begin{tabular}{|c|c|c|c|c|c|c|}
\hline \multirow[b]{2}{*}{ Progress Barrier } & \multicolumn{6}{|c|}{ Project Development Phase } \\
\hline & Prospect & Phase I & Phase II & Phase III & Phase IV & Total \\
\hline No obvious barriers & $20(2)$ & $57(2)$ & $231(7)$ & $37(2)$ & $53(2)$ & $398(15)$ \\
\hline Finance & $357(13)$ & $476(11)$ & $454(11)$ & $230(4)$ & & $\mathbf{1 , 5 1 7}(39)$ \\
\hline PPA acquisition & $223(4)$ & $67(3)$ & $41(3)$ & $159(1)$ & & $490(11)$ \\
\hline Access to capital & (2) & $\mathbb{A}_{329(4)}$ & $173(3)$ & & & $502(9)$ \\
\hline Capital budgeting & $74(6)$ & $80(4)$ & $y_{200(3)}$ & $30(1)$ & & 384 (14) \\
\hline Change in ownership & $60(1)$ & & $40(2)$ & $41(2)$ & & $141(5)$ \\
\hline Permitting & $200(10)$ & $370(9)$ & $45(5)$ & 255 & $30(1)$ & $1,017(28)$ \\
\hline Unspecified delays & $45(7)$ & $50(5)$ & $45(5)$ & $255(3)$ & $30(1)$ & $425(21)$ \\
\hline Cultural & $105(2)$ & $320(1)$ & & & & $425(3)$ \\
\hline Environmental & $50(1)$ & & & & & $50(1)$ \\
\hline Community & & $117(3)$ & & & & $117(3)$ \\
\hline Transmission & $100(1)$ & $70(1)$ & & & & $170(2)$ \\
\hline Resource Uncertainty & $7(3)$ & $35(1)$ & $58(4)$ & $2(1)$ & & $102(9)$ \\
\hline Resource Economics & & - & $50(1)$ & $25(1)$ & & $75(2)$ \\
\hline Legal & $25(3)$ & (3) & $50(1)$ & & & $75(7)$ \\
\hline Construction & & & & & $3(1)$ & $3(1)$ \\
\hline Total & $708(34)$ & $1,131(28)$ & $888(29)$ & $549(11)$ & $86(4)$ & $3,362(106)$ \\
\hline
\end{tabular}

Note: Projected capacities of ongoing or postponed projects are shown by GEA-defined project development phase and by primary recent barrier to project progress.

\subsubsection{Analyzing Geothermal Project Viability}

We used the same analytical process used in the barrier analysis to determine the likelihood of a project coming online by 2020 and its ability to contribute to the doubling goal. These categories are distinct from the determination of project status (operating, postponed, discontinued) because they specifically evaluate the project in respect to the 2020 timeframe. After identifying barriers, we qualitatively evaluated the project for the following characteristics:

- Previous project hurdles, or resolved historical challenges that now allow the project to advance

- Barriers impeding project timelines, particularly any current delays

- Barriers stalling progress that must be resolved before development can continue. 
Based on these evaluation criteria, we classified the project into one of the viability categories presented in Table 6.

Table 6. Categories and Definitions of Project Strategic Viability. Categories are qualitatively assigned based on the combination of a project's barriers and development progress.

\begin{tabular}{|c|l|}
$\begin{array}{c}\text { Viability } \\
\text { Category }\end{array}$ & \multicolumn{1}{c|}{ Description } \\
\hline \hline Likely & Project will come online by 2020 without additional support given current project progress. \\
\hline \hline Potential & $\begin{array}{l}\text { Project needs expedited development to overcome barrier(s) delaying project timelines to } \\
\text { come online by } 2020 .\end{array}$ \\
\hline \hline Stalled & $\begin{array}{l}\text { Project needs significant intervention to remove barrier(s) because the project is so severely } \\
\text { affected by the barrier(s) that future development is halted. }\end{array}$ \\
\hline
\end{tabular}

All projects having a project status of ongoing or postponed were investigated for the viability criteria above. Our analysis does not predict the specific year that projects may come online. SNL Financial provides data on the estimated year online for only a few selected projects. The verification of dates and the determination of timelines for all projects would require interviews with the individual developers and was beyond the scope of this analysis.

\subsection{Results}

Table 7 tabulates projects in our sample dataset and associated progress barriers. Projects capable of producing a combined total of $784 \mathrm{MWe}-21 \%$ of the 2020 goal—face either no development barriers, or barriers that would not likely interfere with project completion by the 2020 deadline. This analysis identifies only present barriers, not barriers that may develop as a project advances. It is possible that some of the $784 \mathrm{MWe}$ found to face either no development barriers or barriers that would not likely interfere with project completion by the 2020 target study date will encounter barriers in the future that prevent deployment by $2020.383 \mathrm{MWe}$ of this $784 \mathrm{MWe}$ $(49 \%)$ are categorized in late stages of project development (GEA Phases III or IV); 401 MWe are categorized as early stage Prospect, Phase I, or Phase II at the time of analysis.

Geothermal project delays related to particular tribal historical and cultural areas are site specific and not widespread. Other issues are more geographically diverse and less location dependent. For example, the most widespread issues are the prioritizing of capital spending on other projects and/or deferring spending on new projects. We would need more information about individual developer's capital budgeting priorities to be able to understand the underlying causes for this reprioritization. These causes might include budgeting related to resource concerns, lack of projected future returns in comparison to other investment options, or an overall lack of sufficient capital for all projects. 
Table 7. Projected Capacity, in Megawatts, of Ongoing or Proposed Projects. Financing is the greatest barrier for both stalled and potential projects.

\begin{tabular}{|c|c|c|c|c|}
\hline \multirow[b]{2}{*}{ Progress Barrier } & \multicolumn{4}{|c|}{2020 Viability } \\
\hline & $\begin{array}{c}\text { STALLED: } \\
\text { Needs } \\
\text { Barrier } \\
\text { Intervention }\end{array}$ & $\begin{array}{c}\text { POTENTIAL: } \\
\text { Needs } \\
\text { Expedited } \\
\text { Development }\end{array}$ & $\begin{array}{l}\text { LIKELY: } \\
\text { Needs No } \\
\text { Additional } \\
\text { Support }\end{array}$ & $\begin{array}{c}\text { Total } \\
2020 \text { Viable } \\
\text { Capacity }\end{array}$ \\
\hline Financing & 1,049 & 375 & 93 & 1517 \\
\hline PPA acquisition & 220 & 177 & 93 & 490 \\
\hline Capital budgeting & 334 & 50 & - & 354 \\
\hline Access to capital & 484 & 18 & - & 502 \\
\hline Change in ownership & 11 & 130 & - & 141 \\
\hline Permitting & 515 & 237 & 265 & 1,017 \\
\hline Cultural & 425 & - & - & 425 \\
\hline Unspecified delays & 40 & 120 & 265 & 425 \\
\hline Community & - & 117 & - & 117 \\
\hline Environmental & 50 & - & - & 50 \\
\hline No obvious barriers & - & - & 398 & 398 \\
\hline Transmission & - & 170 & - & 170 \\
\hline Resource & 108 & 44 & 25 & 178 \\
\hline Uncertainty & 58 & 44 & - & 102 \\
\hline Economics & 50 & - & 25 & 75 \\
\hline Legal & 50 & 25 & - & 75 \\
\hline Technology maturity & - & 5 & - & 5 \\
\hline Construction & - & - & 3 & 3 \\
\hline Totals & 1,722 & 856 & 784 & 3,362 \\
\hline
\end{tabular}

Note: The table does not include capacity of projects for which public information is not available to verify project status or infer current barriers. 
Our analysis suggests that approximately 784 MWe are expected to come online by 2020 (absent future barriers), and an additional $856 \mathrm{MWe}$ could come online if existing barriers could be removed to expedite the project development. Significant support would be needed to bring the 1,024 MWe of stalled, ongoing projects online by 2020. Overcoming barriers may also allow nearly $698 \mathrm{MWe}$ of postponed projects to resume development to come online. Note that these capacities represent only those projects for which we had public information, but additional projects (for which we could find no public information) may also be helped to come online by 2020 if barriers were mitigated. Figure 6 illustrates the total sample dataset (indicated with numbers) as a portion of the total dataset.

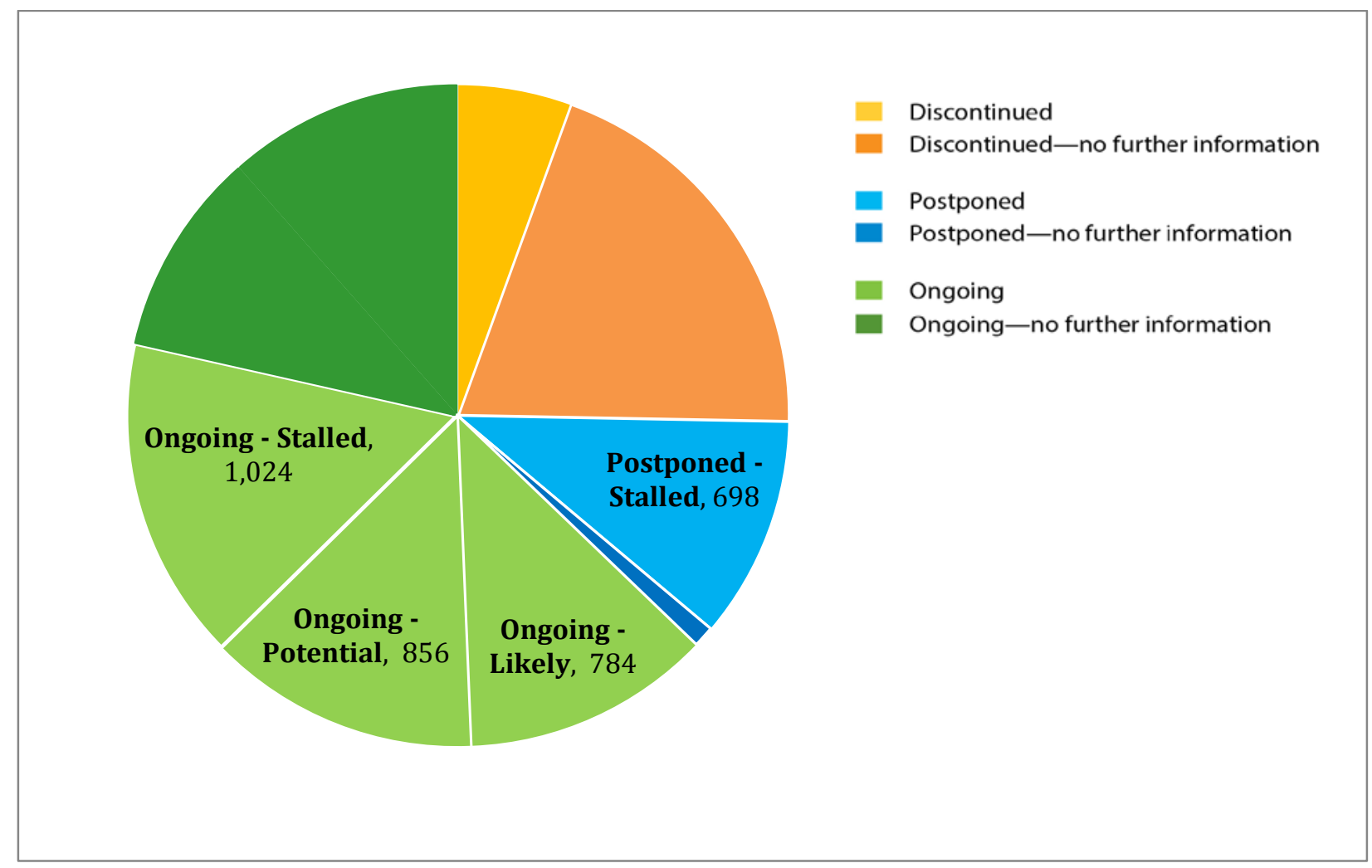

Figure 6. Total project capacity reviewed $(6,441 \mathrm{MWe})$. Updated from Figure 4 to show portion of ongoing projects that are likely, potential and stalled, per Analysis $C$. The majority of project capacity reviewed is categorized as stalled (51\%). Postponed projects were found to be stalled because research does not indicate a likelihood for development to resume to achieve the 2020 goal.

\section{Results Summary and Conclusions}

\subsection{Results Summary}

\section{Analysis A: Where is the project now?}

- Approximately two-thirds of project capacity is located within the first two development phases (Prospect and Phase I). 
Table 8. Analysis A Results

\begin{tabular}{|l|c|c|}
\hline Prospect & $\mathbf{2 , 2 2 8} \mathbf{M W e}$ & $\mathbf{3 5 \%}$ \\
\hline \hline Phase I & $1,987 \mathrm{MWe}$ & $31 \%$ \\
\hline \hline Phase II & $1,411 \mathrm{MWe}$ & $22 \%$ \\
\hline \hline Phase III & $639 \mathrm{MWe}$ & $10 \%$ \\
\hline \hline Phase IV & $111 \mathrm{MWe}$ & $2 \%$ \\
\hline \hline Not Available & $65 \mathrm{MWe}$ & \\
\hline \hline Totals & $6,441 \mathrm{MWe}$ & $100 \%$ \\
\hline
\end{tabular}

\section{Analysis B: Where is the project going?}

- Of the listed capacity in development, 1,629 MWe (25\%) of the 6,441 MWe started since 2012 is associated with projects that have been discontinued. An additional $765 \mathrm{MWe}(12 \%)$ of project capacity is considered postponed indefinitely.

- Projects that developers currently consider to be ongoing include 4,047 MWe (63\%) of nameplate capacity.

\section{Analysis C: Will the project be completed by 2020?}

- Of the 3,362 MWe that had sufficient information to review, we found $784 \mathrm{MWe}$ are expected to come online by 2020 (absent future barriers), and an additional 856 MWe could come online if existing barriers could be removed to expedite the project development.

Table 9. Analysis C Results

\begin{tabular}{|c|c|c|}
\hline LIKELY (ongoing) & $784 \mathrm{MWe}$ & $29 \%$ \\
\hline POTENTIAL (ongoing) & $856 \mathrm{MWe}$ & $32 \%$ \\
\hline STALLED (ongoing) & 1,024 MWe & $39 \%$ \\
\hline Ongoing - no further information & 1,383 MWe & \\
\hline Postponed & $765 \mathrm{MWe}$ & \\
\hline Discontinued & 1,629 MWe & \\
\hline Totals & 5,441 MWe & $100 \%$ \\
\hline
\end{tabular}

- Significant support would be needed to bring the 1,024 MWe of stalled, ongoing projects online by 2020 . 
- Permitting and financing (both external and internal corporate finance priorities) are the major barriers to geothermal development.

- Addressing sources of permitting delays within agency processes (i.e., NEPA) as well as community concerns with geothermal development would potentially benefit at least $1 \mathrm{GWe}$ of capacity under development today.

- Easing PPA negotiations and access to early-stage capital would benefit at least $0.5 \mathrm{GWe}$ under development that is categorized as stalled.

\subsection{Conclusions}

Based on our analysis, the status of potential geothermal capacity that could address the President's 2020 goal is as follows:

- Likely - Needs no additional support - $784 \mathrm{MWe}$

- Potential - Needs expedited development -856 MWe

- Stalled - Needs barrier intervention-1,722 MWe

- Unknown viability or barriers - Ongoing - 1,383 MWe

- Unknown viability or barriers - Postponed - 67 MWe

If all of this 4,812 MWe of ongoing and postponed capacity came online by 2020 it would more than double the current capacity of approximately $3,765 \mathrm{MWe}$. Therefore, our analysis supports a conclusion that there are more than enough geothermal projects under development to double geothermal electricity generation by 2020, but that the majority of these projects are experiencing some barrier, making it unlikely for geothermal electricity generation to double by 2020 without significant actions that overcome these barriers.

The largest barriers are not technical; they are permitting and financing. Of these two barriers, financing - specifically access to capital - seems to be the more significant obstacle. Of the 1,049-MWe of capacity stalled by financing, $484 \mathrm{MWe}(46 \%)$ is related to the lack of sufficient funding for further exploration.

Overcoming barriers on an industry-wide level could allow for deployment of 4,047 MWe of ongoing projects, and $765 \mathrm{MWe}$ of postponed projects - enough to more than double the current installed geothermal capacity in the United States. 


\section{References}

BLM. 2007. 43 CFR Parts 3000, 3200, and 3280 Geothermal Resource Leasing and Geothermal Resources Unit Agreements; Final Rule. Washington, DC: U.S. Department of the Interior/BLM. Accessed September 9, 2015.

http://www.blm.gov/or/programs/minerals/files/geothermal_resources_agreements.pdf.

EIA. 2013. State Electricity Profiles. Accessed November 9, 2105.

http://www.eia.gov/electricity/state/unitedstates/.

- 2015. Electricity: Form EIA-860 Detailed Data. Washington, DC: EIA. Accessed September 9, 2015. http://www.eia.gov/electricity/data/eia860/.

Executive Office of the President 2013a. Executive Office of the President. June 2013. The President's Climate Action Plan. Accessed September 9, 2015:

http://www.whitehouse.gov/sites/default/files/image/president27sclimateactionplan.pdf.

- 2013b. FACT SHEET: Presidential Memorandum on Federal Leadership on Energy Management. Accessed September 9, 2015. https://www.whitehouse.gov/the-pressoffice/2013/12/05/fact-sheet-presidential-memorandum-federal-leadership-energy-management.

Flóvenz, Ó.G. 2013. "Phases of Geothermal Development." Presented at the Renewable Energy Training Program, Module 3 - Geothermal Energy, Reykjavík, Iceland. Accessed September 9, 2015. http://www.esmap.org/sites/esmap.org/files/Flovenz\%20Day\%201\%20-WB-2-phasesfinal.pdf.

Gawell, K. 2014. Statement of Karl Gawell Before the Senate Select Committee on California's Energy Independence \& Assembly Select Committee on Renewable Energy Economy in Rural California. Accessed September 9, 2015. http://geoenergy.org/reports/FinalGEAStatementforApril3.pdf.

GEA. April 2014. 2014 Annual U.S. \& Global Geothermal Power Production Report. Washington, DC: GEA. Accessed September 9, 2015. http://geoenergy.org/events/2014\%20Annual\%20US\%20\&\%20Global\%20Geothermal\%20Power\%20Prod uction\%20Report\%20Final.pdf.

- April 2013. 2013 Annual US Geothermal Power Production and Development Report. Washington, DC: GEA. Accessed September 9, 2015: http://geoenergy.org/pdf/reports/2013AnnualUSGeothermalPowerProductionandDevelopmentReport_Final .pdf.

April 2012. Annual US Geothermal Power Production and Development Report.

Washington, DC: GEA. Accessed September 9, 2015. http://geoenergy.org/reports/2012AnnualUSGeothermalPowerProductionandDevelopmentReport Final.pdf

November 2010. New Geothermal Terms and Definitions: A Guide to Reporting Resource Development Progress and Results to the Geothermal Energy Association. Washington, 
DC: GEA. Accessed September 9, 2015. http://geo-

energy.org/pdf/NewGeothermalTermsandDefinitions_January2011.pdf.

GeothermEx. 2004. New Geothermal Site Identification and Qualification. Sacramento, CA:

California Energy Commission Public Interest Energy Research Program. Accessed September 9, 2015. http://www.energy.ca.gov/reports/500-04-051.PDF.

Glacier Partners. October 2009. 3.5-Year Development Timeline.

http://www.georestore.com/cms_files/Geothermal\%20Economics\%20101\%20-

$\% 20$ Glacier\%20Partners.pdf.

Islandsbanki Geothermal Research. 2011. U.S. Geothermal Industry Overview. Accessed September 9, 2015.

http://skjol.islandsbanki.is/servlet/file/store156/item79399/U.S.\%20Geothermal\%20Industry\%20

Overview.pdf

Neeley, K.W., and G. Galinato. 2007. Geothermal Power Generation in Idaho: An Overview of Current Developments and Future Potential. State of Idaho. Accessed September 9, 2015. http://www.energy.idaho.gov/informationresources/d/geo_power_generation_in_idaho.pdf.

Glacier Partners. September 22, 2009. Personal Interview.

Nordquist, J., Ormat. September 22, 2015. Personal Interview.

OpenEI. July 2014. Geothermal Energy: Geothermal Regions. Accessed September 9, 2015. http://en.openei.org/wiki/Geothermal_Regions.

SNL Financial. 2014. "Power Plant Units." SNL Financial Power Plant Search. Accessed August 4-September 4 2014. https://www.snl.com/interactivex/bbsearch.aspx?persp=plant.

USGS. 2008. Assessment of Moderate- and High-Temperature Geothermal Resources of the United States. Reston, VA: USGS. Accessed September 9, 2015.

http://energy.usgs.gov/GeneralInfo/EnergyNewsroomAll/TabId/770/ArtMID/3941/ArticleID/730/ Assessment-of-Moderate-and-High-Temperature-Geothermal-Resources-of-the-United-

States.aspx.

Young, K.R., T. Reber, and K. Witherbee. 2012. Hydrothermal Exploration Best Practices and Geothermal Knowledge Exchange on OpenEI. PROCEEDINGS, Thirty-Seventh Workshop on Geothermal Reservoir Engineering. Stanford University, Stanford, California, January 30 February 1, 2012. SGP-TR-194.

http://www.geothermal-energy.org/pdf/IGAstandard/SGW/2012/Young.pdf? 


\section{APPENDIX A: Comparison of Geothermal Nameplate and Summer Capacities}

This analysis considers nameplate capacity because this value is the rated maximum output that the plant could sustain. Many power plants generate power below this nameplate capacity in the summer and above the nameplate capacity in the winter. Nameplate capacity is most relevant to this report's analysis because it is the quantity reported by developers in all stages of project development prior to power plant construction. Net summer capacity, is the reported plant output to the grid that a plant provides during the summer, though there are no reporting requirements provided for when this summer capacity is measured (e.g. average summer capacity, maximum summer capacity, time of day: morning, afternoon, night). The net summer capacity, however reported, is less than the nameplate for several reasons, including 1) it is the net capacity delivered to the grid after on-site power uses for activities such as well pumping, and 2) lower efficiency in summer due to the smaller brine-ambient air temperature differential. While net capacity represents the quantity of power available to the grid during the summer, this value is not known until a plant is operational.

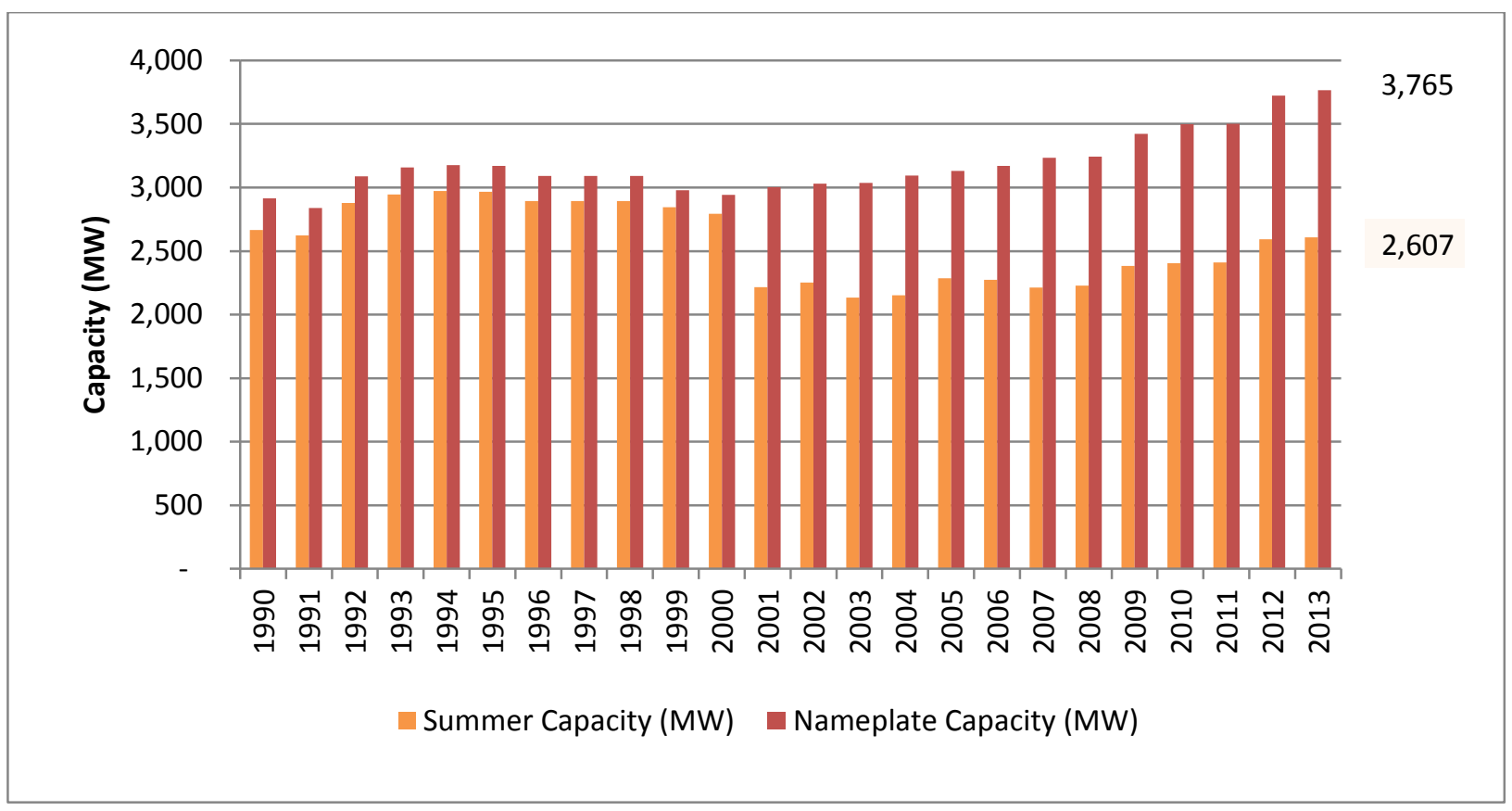

Figure A1. Comparison of Nameplate to Net Summer Capacity, 1990-2013. Figure shows current discrepancy between installed nameplate capacity (design output of installed projects) to net summer capacity (net output of geothermal power available for sale during the summer). As of 2013, EIA survey data from geothermal generators shows that geothermal nameplate capacity was 3,765 MW in comparison to 2,607 MW reported net summer capacity. Sources: Energy Information Association (2015) Nameplate Capacity: Form 860 Generator Data, State Electricity Profiles (July 2015). Summer Capacity: Annual Energy Review (2015). 


\section{APPENDIX B: Analysis D: How Much Additional Geothermal Potential Energy Can be Deployed?}

\section{B.1 Data Sources}

We found no recent studies of undeveloped resource capacity by geothermal area. The estimates of resource potential in this report are published estimates (e.g., GeothermEx 2004) adjusted for the additional capacity that has come online since the estimate publication date. We used the following information to estimate geothermal resource potential:

- Company-reported estimates from press releases, websites, and/or financial reports

- Annual reports, company websites, press releases, and notices of asset sales

- Literature or published estimates from federal or state agencies (e.g. USGS 2008), companies, consulting groups, and/or industry associations

- Project data aggregation from reported GEA project resource capacity or possible capacity as reported by SNL Financial. When the resource estimates were equal to or greater than the possible resource capacity, we used GEA resource estimates. When inadequate data were available, we used potential project capacity in development as resource capacity.

The aggregation of project capacity in development from GEA and SNL Financial estimates served as a minimum conservative estimate of potential.

When there was limited publicly available information about a geothermal area, we conducted interviews to gain more information about projects in that area. ${ }^{3}$

The source of geothermal nameplate capacity currently online came from unit-level data reported on the EIA Form 860 (EIA 2015). We developed capacity-online assessments for geothermal areas from a combination of the reported unit nameplate capacity, the unit status (i.e., operating/online), and the locations and counties of the units.

\section{B.2 Methodology}

This analysis did not quantitatively review all geothermal areas for their potential. We selected the areas with both the highest resource potential (i.e., resource capacity less operating capacity) and the perceived highest developer experience. From this selection we chose the top areas based on the following characteristics:

- Areas with combined project resource capacity (based on aggregated project capacity in development from GEA reports and SNL Financial database)

- Geothermal area resource capacity identified from third-party reports (GEA 2015, 2014, 2013, 2012; GeothermEx 2004)

- Review of landowner history of success with geothermal development (i.e., are the leases owned by a large, established developer, or by a small independent?)

- Review of investment analyst reports for their opinions on the industry, companies, and prospects (Islandsbanki Geothermal Research (2011)).

\footnotetext{
${ }^{3}$ Personal communication between Brian Fairbanks (Alternate Energy Resources) and Kermit Witherbee (NREL), May 13-15, 2014.
} 


\section{B.3 Analysis}

The method we used to develop estimates of the top 10 areas of additional resource potential is as follows:

- Research studies of resource potential by geothermal area:

- Create a unique list of geothermal projects with reported resource capacity and/or planned capacity

- Review company-reported estimates of potential, via financial reports and interviews

- Review third-party studies of resource potential within geothermal areas.

- Identify capacity in development by geothermal area:

- Create a unique list of geothermal projects under development and their characteristics

- Research the project's most recent events (or lack thereof) to identify the barriers to project progress

- Categorize the likelihood that these barriers severely impede near-term project development

- Aggregate project capacity by geothermal area and barrier.

- Identify capacity currently online by geothermal area.

- Aggregate unit-level company-reported data into geothermal areas.

\section{B.4 Results}

If the barriers summarized in Table 7 cannot be addressed in the near term, the analysis of resource potential shows that significant resource capacity may remain undeveloped (Table B1). Table B1 identifies more than $1.5 \mathrm{GW}$ of untapped potential within the Salton Sea, the Geysers, and the Dixie Valley areas.

For example, the Gulf of California Rift Zone is an area known to have high geothermal potential. Yet our analysis of project status (Figure 5) showed that a majority (634/824 MWe, 77\%) of the projects in this region have been postponed or discontinued. Table B1 suggests that there is an additional 1,823 MWe (Salton Sea, East Brawley) of high-potential resource that remains undeveloped, likely due to local development barriers. The East Brawley Area shows a Capacity in Development (210 MWe) greater than the Additional Resource Potential (129 MWe). Though we have not researched the reason for this discrepancy, we suspect that the developers have more detailed data on resource (suggesting higher certainty) than did the references reporting potential.

Additional research is needed to determine why these areas are not being developed and to understand what additional barriers are preventing larger-scale development. 
Table B1. Top Resource Areas for Geothermal Development. Of the 11 reviewed, 5 areas have operational capacity online. Seven areas would have additional capacity remaining for development if current projects are completed.

\begin{tabular}{|c|c|c|c|c|c|c|c|c|}
\hline $\begin{array}{l}\text { Geothermal } \\
\text { Area / KGRA }\end{array}$ & 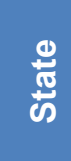 & County & $\begin{array}{l}\text { Operational } \\
\text { Capacity } \\
\text { Online }\end{array}$ & \multicolumn{2}{|c|}{$\begin{array}{l}\text { Additional } \\
\text { Resource } \\
\text { Potential in } \\
\text { MW (ref) }\end{array}$} & $\begin{array}{l}\text { Capacity In } \\
\text { Development } \\
\text { in MW }\end{array}$ & $\begin{array}{l}\text { Balance } \\
\text { Remaining } \\
\text { in MW }\end{array}$ & $\begin{array}{c}\text { Largest } \\
\text { Current } \\
\text { Development } \\
\text { Hurdle }\end{array}$ \\
\hline Salton Sea & $\mathrm{CA}$ & Imperial & 437 & 1,663 & (3) & 50 & 1613 & Permit Delays \\
\hline Geysers & $\mathrm{CA}$ & $\begin{array}{l}\text { Sonoma/ } \\
\text { Lake }\end{array}$ & 1,585 & 815 & (3) & 401 & 414 & $\begin{array}{c}\text { PPA } \\
\text { Acquisition }\end{array}$ \\
\hline $\begin{array}{l}\text { Glass } \\
\text { Mountain }\end{array}$ & $\mathrm{CA}$ & Siskiyou & 0 & 211 & (3) & 50 & 161 & $\begin{array}{c}\text { Cultural/ } \\
\text { Environmental }\end{array}$ \\
\hline East Brawley & $\mathrm{CA}$ & Imperial & 0 & 129 & (3) & 210 & 0 & $\begin{array}{l}\text { Access to } \\
\text { Capital }\end{array}$ \\
\hline Silver Peak & NV & Esmeralda & 0 & 160 & (1) & 160 & 0 & $\begin{array}{l}\text { Insufficient } \\
\text { Information }\end{array}$ \\
\hline Lee Allen & NV & Churchill & 190 & 145 & (2) & 145 & 0 & $\begin{array}{l}\text { Insufficient } \\
\text { Information }\end{array}$ \\
\hline Renaissance & UT & Box Elder & 0 & 100 & (1) & 0 & 100 & $\begin{array}{l}\text { Access to } \\
\text { Capital }\end{array}$ \\
\hline $\begin{array}{l}\text { Willow } \\
\text { Springs }\end{array}$ & ID & Bonneville & 18 & 100 & (4) & 100 & 0 & Transmission \\
\hline Crane Creek & ID & Washington & 0 & 179 & (4) & 50 & 129 & $\begin{array}{l}\text { Insufficient } \\
\text { Information }\end{array}$ \\
\hline Dixie Valley & NV & Churchill & 60.5 & 342 & (2) & 51 & 291 & $\begin{array}{c}\text { PPA } \\
\text { Acquisition }\end{array}$ \\
\hline Mammoth & CA & Mono & 37 & 111 & (3) & 30 & 81 & Permit Delays \\
\hline Totals & & & $2,327.5$ & 4,395 & & 1,247 & 2,789 & \\
\hline
\end{tabular}

KGRA: known geothermal resource area

Source: Operating capacity from EIA Form 860 generator nameplate capacity, 2014. Additional resource capacity determined from the following sources:

- Estimates from GEA and SNL data compiled for this analysis

- Geothermex (2004)

- Gawell, K. (2014)

- Neeley, K.W. and Galinato, G. (2007). 